Igor Lukić ${ }^{1}$, Nevena Ranković2, Dragica Ranković ${ }^{3}$

\title{
PROCENA RIZIKA ZA NASTANAK DIJABETESA TIP 2 USLOVLJENA NAVIKAMA U ISHRANI KOD ADOLESCENATA
}

Sažetak: U ovom radu biće prikazani rezultati istraživanja o navikama u ishrani kod adolescenata. Srednjoškolsko, odnosno adolescentno doba jeste doba velikih fizičkih i psihičkih promena, koje izazivaju nestabilnost i oscilacije u raspoloženju i ponašanju srednjoškolaca. Rezultati dobijeni anketiranjem učenika srednjih škola o navikama u ishrani i rezultati dobijeni korišćenjem standardizovanog upitnika za rizik nastanka dijabetesa tipa 2 analizirani su uz pomoć pouzdanog statističkog alata IBM SPSS Statistical, koji nudi niz pouzdanih analiza i statističkih testova. Dosadašnja istraživanja su pokazala da na svaku osobu koja ima dijabetes tipa 2, dolazi po jedna osoba koja ne zna da ga ima. Otkrivanje preddijabetesa kod novih potencijalnih pacijenata je neophodno u najranijem uzrastu, kada niz faktora $u$ načinu života, kao što su nepravilna ishrana i gojaznost, fizička neaktivnost, stres i drugi, postaju važni za razvoj ove bolesti. Otkrivanje stepena rizika kod potencijalnih pacijenata je važno kako za samog pojedinca tako i za javno zdravstvo i svakodnevnu kliničku praksu. Nakon utvrđivanja stepena rizika kod određenog uzorka, biće preporučeno niz mera za određenu populaciju adolescenata, kako do nastanka bolesti ne bi došlo, ili bi se njen početak pomerio za kasniji period života.

Ključne reči: ishrana, dijabetes tip 2, adolescenti, faktori rizika

Engleska verzija ovog rada objavljena je u časopisu Medicinski glasnik, broj 79 . Igor Lukić, doktorske studije, Medicinski fakultet, Kragujevac.

2 Nevena Ranković, računarske nauke, PMF, Novi Sad.

3 Dragica Ranković, Medicinska škola 'Dr Miša Pantić', Valjevo. 


\section{Uvod}

Dijabetes tipa 2 predstavlja insulinsko nezavisni tip dijabetesa, kod koga je smanjeno lučenje insulina (1). Može se javiti u bilo kom uzrastu, ali najčešće kod gojaznih osoba. U poslednjih desetak godina kod značajnog broja adolescenata prisutna je ekstremna gojaznost, uzrokovana u najvećoj meri nepravilnom ishranom, nedovoljnom fizičkom aktivnošću, stresom i slično (2). Uporedo sa porastom gojaznosti dolazi do porasta i dijabetesa tipa 2, oboljenja srca, moždanog udara, dijabetesne retinopatije, koja ima uticaja na vid, otkazivanje rada bubrega, što kao posledicu ima dijalizu, do loše cirkulacije u najčešće donjim ekstremitetima, što može uzrokovati amputacije ekstremiteta i mnoge druge bolesti (3),(4),(5).

Dijabetes tipa 2, koji je ranije imao najveću učestalost kod starijih osoba, počinje eksponencijalno da raste i kod dece, a posebno u periodu puberteta ili adolescencije (6), (7). U poslednjih desetak godina kod značajnog broja adolescenata prisutna je ekstremna gojaznost, uzrokovana u najvećoj meri nepravilnom ishranom, nedovoljnom fizičkom aktivnošću, stresom i na slično. (8) Uporedo sa porastom gojaznosti dolazi do porasta i dijabetesa tipa 2 (9),(10). Mnoga istraživanja u zemlji i inostranstvu pokazuju da se redukovanim unosom određenih namirnica, može redukovati telesna težina, a samim tim i rizik od nastanka ove bolesti (11), (5).

\section{Struktura uzorka}

$\mathrm{U}$ istraživanju koje će biti predstavljeno u ovom radu učestvovalo je ukupno 318 učenika srednjih škola sa područja kolubarskog okruga. Strukturu uzorka čine: $145(45,6 \%)$ učenika muškog pola i $173(54,4 \%)$ učenika ženskog pola. Posmatrano po razredima koje trenutno uče, strukturu naših ispitanika čine: $71(22,3 \%)$ učenik prve godine, $89(28,0 \%)$ učenika druge godine, 79 (24,8\%) učenika treće godine i 79 $(24,8 \%)$ učenika četvrte godine. Sredina iz koje dolaze učenici: gradska sredina 113 $(35,5 \%)$ učenika, prigradska sredina $114(35,8 \%)$ učenika i seoska sredina $91(28,7 \%)$ učenika. Statistički značajnih razlika nema ni prema polu, ni razredu, ni sredini iz koje učenici dolaze. (Tabela 1.)

Tabela 1. Struktura uzorka ispitanika

\begin{tabular}{|c|c|c|c|c|c|}
\hline \multicolumn{2}{|c|}{ Struktura uzorka ispitanika } \\
\hline \multirow{3}{*}{ Pol } & & $\begin{array}{c}\text { Frequency } \\
\text { \% }\end{array}$ & Percent & CS & CS(p) \\
\cline { 2 - 4 } & male & 145 & 45.6 & \multirow{2}{*}{2.465} & \multirow{2}{*}{0.116} \\
\hline
\end{tabular}




\begin{tabular}{|c|c|c|c|c|c|}
\hline \multirow{4}{*}{ Razred } & 1. razred & 71 & 22.3 & \multirow{4}{*}{2.050} & \multirow{4}{*}{0.562} \\
\hline & 2. razred & 89 & 28.0 & & \\
\hline & 3. razred & 79 & 24.8 & & \\
\hline & 4. razred & 79 & 24.8 & & \\
\hline \multirow{3}{*}{ Sredina } & gradska & 113 & 35.5 & \multirow{3}{*}{3.489} & \multirow{3}{*}{0.175} \\
\hline & prigradska & 114 & 35.8 & & \\
\hline & seoska & 91 & 28.7 & & \\
\hline
\end{tabular}

\section{Predmet istraživanja}

Učenici su u prvom delu istraživanja popunjavali anonimni anketni upitnik, koji govori o njihovim navikama u ishrani i konzumiranju određene vrste hrane i pića. Prvi deo upitnika, pored osnovnih podataka kao što su pol ispitanika, razred koji trenutno pohađaju i sredina iz koje dolaze, sadrži i pitanje o njihovoj proceni, mišljenju o pravilnosti svoje ishrane. U drugoj grupi pitanja učenici su ocenjivali koliko prosečno konzumiraju navedene vrste namirnica kao što su: riba, meso, mleko i mlečni proizvodi, hleb, testa i peciva, voće, povrće, kolači, slatkiši, voda, voćni sokovi, energetska i gazirana pića. Treću grupu pitanja činila su pitanja vezana za postojanje zdravstvenih poteškoća ili naslednih bolesti, držanje dijeta, njihova mišljenja i stavove o dijetama, da li obavezno doručkuju i uopšte uticaju hrane na zdravlje (6).

Drugi deo istraživanja odnosio se na rizik od nastanka dijabetesa tip 2. U istraživanju, od 318 učenika 111 učenika dobrovoljno su želeli da popune online standardizovani upitnik, 48 (43,2\%) učenika muškog pola i $63(56,7 \%)$ učenika ženskog pola. Budući da većina ispitanika ne zna vrednost indeksa telesne mase (BMI), najpre je napravljen kratak online upitnik za njegovo izračunavanje iz kojeg je precizno moguće dobiti traženu tačnu vrednost. Standardizovani upitnik za rizik od nastanka dijabetesa tipa 2 sadrži 8 pitanja, na koje učenici, koji žele, mogu odgovoriti. U njemu je dodata opcija „pol”, kako bi se mogli uporediti odgovori učenika prema ovom kriterijumu. Sabiranjem bodova dobijenih na osnovu ovih 8 odgovora dobijamo broj koji predstavlja procenu rizika od nastanka dijabetesa tip 2 (7).

\section{Korišćena metodologija}

Rezultati dobijeni korišćenjem anketnog upitnika analizirani su pomoću pouzdanog statističkog alata IBM SPSS Statistical, koji nudi niz pouzdanih analiza i statističkih testova. Za odgovore učenika na petostepenoj Likert scale: (1 means very 
bad, 2 means bad, 3 means satisfactory, 4 means good, 5 means very good) korišćen je Kruskal Wallisov H Test KW(H) i njegova značajnost KW(p). Za analizu pitanja sa odgovorima Yes/Neutral/No korišćen je Chi-Square test (CS) i njegova značajnost $\mathrm{CS}(\mathrm{p})$. Za analizu dobijenih rezultata kod online testa za rizik od nastajanja dijabetesa tip 2 pitanja korišćeni su: Mean i One-Way ANOVA test kod upoređivanja odgovora studenata muškog i ženskog pola (12), (13), (14).

Postavljene hipoteze $\mathrm{u}$ istraživanju:

H1: Kod adolescenata uzrasta 14 do 18 godina nema statistički značajnih razlika u konzumiranju različitih namirnica posmatrano prema polu, uzrastu, ni sredini u kojoj žive.

H2: Mali procenat (manje od 15\%) adolescenata ima rizik od nastanka dijabetesa tip 2, posmatrano prema polu ispitanika.

\section{Analiza dobijenih rezultata}

Učenici su na prvo postavljeno pitanje davali svoje mišljenje o sopstvenom načinu ishrane. Učenici muškog pola, 12,7\%, smatraju da se pravilno hrane, delimično pravilno se hrani velika većina $69,0 \%$, učenika, dok $18,3 \%$ učenika smatra da se hrani nepravilno. Učenici ženskog pola, $12,5 \%$, smatraju da se pravilno hrane, delimično pravilno se njih velika većina, $78,5 \%$, učenika, dok $9,0 \%$ učenika smatra da se hrani nepravilno. U odgovorima učenika posmatrano prema polu nema statistički značajnih razlika. (Tabela 2)

Tabela 2. Mišljenja učenika o svojoj ishrani prema polu, razredu i sredini iz koje dolaze

\begin{tabular}{|c|c|c|c|c|c|c|}
\hline \multicolumn{7}{|c|}{ Mišljenja učenika o svojoj ishrani prema polu, razredu i sredini iz koje dolaze } \\
\hline & Pol & Yes $\%$ & Neutral \% & No $\%$ & $\mathrm{KW}(\mathrm{H})$ & KW(p) \\
\hline \multirow[b]{2}{*}{ Pol } & male & 12.7 & 69.0 & 18.3 & \multirow{2}{*}{2.538} & \multirow[b]{2}{*}{0.111} \\
\hline & female & 12.5 & 78.5 & 9.0 & & \\
\hline \multirow{4}{*}{ Razred } & 1. razred & 11.3 & 70.4 & 18.3 & \multirow{4}{*}{3.376} & \multirow{4}{*}{0.337} \\
\hline & 2. razred & 20.9 & 65.1 & 14.0 & & \\
\hline & 3. razred & 9.0 & 82.0 & 9.0 & & \\
\hline & 4. razred & 8.0 & 80.0 & 12.0 & & \\
\hline \multirow[b]{3}{*}{ Sredina } & gradska & 13.7 & 75.2 & 11.1 & \multirow{3}{*}{0.810} & \multirow[b]{3}{*}{0.667} \\
\hline & prigradska & 12.7 & 72.7 & 14.6 & & \\
\hline & seoska & 10.0 & 74.4 & 14.6 & & \\
\hline
\end{tabular}

Učenici prvog razreda, njih 11,3\%, smatra da se pravilno hrani, delimično pravilno se hrani velika većina, $70,4 \%$ učenika, dok $18,3 \%$ smatra da se hrani nepravilno. Učenici drugog razreda, 20,9\%, smatraju da se pravilno hrane, delimično pravilno 
velika većina, $65,1 \%$ učenika, dok $14,0 \%$ smatra da se hrani nepravilno. Učenici trećeg razreda, 9,0\%, smatraju da se pravilno hrane, delimično pravilno velika većina, $82,0 \%$ učenika, dok $9,0 \%$ učenika smatra da se hrani nepravilno. Učenici četvrtog razreda, $8,0 \%$, smatraju da se pravilno hrane, delimično pravilno velika većina, $80,0 \%$ učenika, dok njih $12,0 \%$ smatra da se hrani nepravilno. U odgovorima učenika posmatrano prema polu nema statistički značajnih razlika. (Tabela 2.)

Učenici iz gradske sredine, njih 13,7\%, smatraju da se pravilno hrane, delimično pravilno velika većina, $75,2 \%$ učenika, dok njih $11,1 \%$ smatra da se hrani nepravilno. Učenici iz prigradske sredine $12,7 \%$, smatraju da se pravilno hrane, delimično pravilno velika većina, $72,7 \%$ učenika, dok $14,6 \%$ smatra da se hrani nepravilno. Učenici iz seoske sredine, $10.0 \%$, smatraju da se pravilno hrane, delimično pravilno velika većina, $74,4 \%$ učenika, dok $14,6 \%$ smatra da se hrani nepravilno. U odgovorima učenika posmatrano prema polu nema statistički značajnih razlika. (Tabela 2.)

Drugi deo upitnika se odnosi na navike učenika u konzumiranju određenih grupa namirnica. Analizom odgovora učenika muškog pola $(2,71)$ i ženskog pola $(2,66)$ nema statistički značajnih razlika u konzumiranju ribe i proizvoda od ribe. U odgovorima učenika prvog razreda $(2,71)$, drugog razreda $(2,60)$, trećeg razreda $(2,75)$ i četvrtog razreda $(2,68)$ nema statistički značajnih razlika. U odgovorima učenika iz gradske sredine $(2,54)$, iz prigradske sredine $(2,93)$ i seoske sredine $(2,53)$ postoje statistički značajne razlike. (Tabela 3.)

Tabela 3. Odgovori učenika o konzumiranju ribe i proizvoda od ribe prema polu, razredu i sredini iz koje dolaze

\begin{tabular}{|c|c|c|c|c|}
\hline \multicolumn{5}{|c|}{ Koliko konzumirate ribu i proizvode od ribe? } \\
\hline & & Mean & KW(H) & $\mathrm{KW}(\mathrm{p})$ \\
\hline \multirow[b]{2}{*}{ Pol } & male & 2.71 & \multirow[b]{2}{*}{0.252} & \multirow[b]{2}{*}{0.615} \\
\hline & female & 2.66 & & \\
\hline \multirow{4}{*}{ Razred } & 1. razred & 2.71 & \multirow{4}{*}{1.182} & \multirow{4}{*}{0.757} \\
\hline & 2. razred & 2.60 & & \\
\hline & 3. razred & 2.75 & & \\
\hline & 4. razred & 2.68 & & \\
\hline \multirow{3}{*}{ Sredina } & gradska & 2.54 & \multirow{3}{*}{9.787} & \multirow{3}{*}{0.007} \\
\hline & prigradska & 2.93 & & \\
\hline & seoska & 2.53 & & \\
\hline
\end{tabular}

Analizom odgovora učenika muškog pola $(3,24)$ i ženskog pola $(2,87)$ postoje statistički značajne razlike u konzumiranju mesa i proizvoda od mesa. U odgovorima učenika prvog razreda $(3,01)$, drugog razreda $(2,94)$, trećeg razreda $(3,16)$ i četvrtog razreda $(3,04)$ nema statistički značajnih razlika. U odgovorima učenika iz gradske 
sredine $(3,08)$, iz prigradske sredine $(2,99)$, i seoske sredine $(3,04)$ ne postoje statistički značajne razlike. (Tabela 4.)

Tabela 4. Odgovori učenika o konzumiranju mesa i proizvoda od mesa prema polu, razredu i sredini iz koje dolaze učenici

\begin{tabular}{|c|c|c|c|c|}
\hline \multicolumn{5}{|c|}{ Koliko konzumirate meso i proizvode od mesa? } \\
\hline \multirow{3}{*}{ Pol } & & Mean & KW(H) & KW(p) \\
\hline \multirow{4}{*}{ Razred } & male & 3.24 & \multirow{2}{*}{9.667} & \multirow{2}{*}{0.002} \\
\cline { 2 - 3 } & female & 2.87 & & \\
\cline { 2 - 3 } & 1. razred & 3.01 & \multirow{2}{*}{2.410} & \multirow{2}{*}{0.492} \\
\cline { 2 - 3 } & 2. razred & 2.94 & \\
\hline \multirow{4}{*}{ Sredina } & 3. razred & 3.16 & & \\
& 4. razred & 3.04 & & \\
& gradska & 3.08 & & \\
& prigradska & 2.99 & & \\
\cline { 2 - 3 } & seoska & 3.04 & & \\
\hline
\end{tabular}

Analizom odgovora učenika muškog pola $(3,74)$ i ženskog pola $(3,78)$ ne postoje statistički značajne razlike u konzumiranju mleka i mlečnih proizvoda. U odgovorima učenika prvog razreda $(3,80)$, drugog razreda $(3,74)$, trećeg razreda $(3,85)$ i četvrtog razreda $(3,67)$ nema statistički značajnih razlika. U odgovorima učenika iz gradske sredine $(3,79)$, iz prigradske sredine $(3,68)$ i seoske sredine $(3,85)$ ne postoje statistički značajne razlike. (Tabela 5.)

Tabela 5. Odgovori učenika o konzumiranju mleka i mlečnih proizvoda prema polu, razredu i sredini iz koje dolaze učenici

\begin{tabular}{|c|c|c|c|c|}
\hline \multicolumn{5}{|c|}{ Koliko konzumirate mleko i mlečne proizvode? } \\
\hline & & Mean & $\mathrm{KW}(\mathrm{H})$ & KW(p) \\
\hline \multirow[b]{2}{*}{ Pol } & male & 3.74 & \multirow[b]{2}{*}{0.400} & \multirow[b]{2}{*}{0.527} \\
\hline & female & 3.78 & & \\
\hline \multirow{4}{*}{ Razred } & 1. razred & 3.80 & \multirow{4}{*}{1.892} & \multirow{4}{*}{0.595} \\
\hline & 2. razred & 3.74 & & \\
\hline & 3. razred & 3.85 & & \\
\hline & 4. razred & 3.67 & & \\
\hline \multirow{3}{*}{ Sredina } & gradska & 3.79 & \multirow{3}{*}{1.576} & \multirow{3}{*}{0.455} \\
\hline & prigradska & 3.68 & & \\
\hline & seoska & 3.85 & & \\
\hline
\end{tabular}


Analizom odgovora učenika muškog pola $(3,61)$ i ženskog pola $(3,41)$ ne postoje statistički značajne razlike u konzumiranju hleba, testa i peciva. U odgovorima učenika prvog razreda $(3,61)$, drugog razreda $(3,49)$, trećeg razreda $(3,66)$ i četvrtog razreda $(3,56)$ nema statistički značajnih razlika. U odgovorima učenika iz gradske sredine $(3,58)$, iz prigradske sredine $(3,62)$, i seoske sredine $(3,51)$ ne postoje statistički značajne razlike. (Tabela 6.)

Tabela 6. Odgovori učenika o konzumiranju hleba, testa i peciva prema polu, razredu i sredini iz koje dolaze učenici

\begin{tabular}{|c|c|c|c|c|}
\hline \multicolumn{5}{|c|}{ Koliko konzumirate hleba, testa i peciva? } \\
\hline \multirow{3}{*}{ Pol } & Pol & Mean & KW(H) & KW(p) \\
\hline \multirow{4}{*}{ Razred } & male & 3.61 & \multirow{2}{*}{0.565} & 0.452 \\
\cline { 2 - 3 } & female & 3.41 & & \\
& 1. razred & 3.61 & \multirow{2}{*}{1.114} & \multirow{2}{*}{0.767} \\
\cline { 2 - 3 } & 2. razred & 3.49 & \\
\cline { 2 - 3 } Sredina & 3. razred & 3.66 & \multirow{2}{*}{0.672} & \multirow{2}{*}{0.715} \\
\cline { 2 - 3 } & 4. razred & 3.56 & \\
\cline { 2 - 3 } & gradska & 3.58 & \\
\cline { 2 - 3 } & prigradska & 3.62 & & \\
\hline
\end{tabular}

Analizom odgovora učenika muškog pola $(3,47)$ i ženskog pola $(3,59)$ postoje statistički značajne razlike u konzumiranju voća i povrća. U odgovorima učenika prvog razreda $(3,01)$, drugog razreda $(2,94)$, trećeg razreda $(3,16)$ i četvrtog razreda $(3,04)$ nema statistički značajnih razlika. U odgovorima učenika iz gradske sredine $(3,08)$, iz prigradske sredine $(2,99)$ i seoske sredine $(3,04)$ postoje statistički značajne razlike. (Tabela 7.)

Tabela 7. Odgovori učenika o konzumiranju voća i povrća prema polu, razredu i sredini iz koje dolaze učenici

\begin{tabular}{|c|c|c|c|c|}
\hline \multicolumn{5}{|c|}{ Koliko konzumirate voća i povrća? } \\
\hline \multirow{3}{*}{ Pol } & Pol & Mean & \multirow{2}{*}{ KW(H) } & \multirow{2}{*}{ KW(p) } \\
\hline \multirow{4}{*}{ Razred } & male & 3.47 & \multirow{2}{*}{0.655} & 0.418 \\
\cline { 2 - 3 } & female & 3.59 & \multirow{2}{*}{5.389} & \multirow{2}{*}{0.146} \\
\cline { 2 - 3 } & 1. razred & 3.59 & \\
\cline { 2 - 3 } & 2. razred & 3.73 & \multirow{2}{*}{6.214} & \multirow{2}{*}{0.045} \\
\cline { 2 - 3 } & 3. razred & 3.45 & \\
\hline \multirow{3}{*}{ Sredina } & 4. razred & 3.33 & \\
& gradska & 3.58 & & \\
\cline { 2 - 3 } & prigradska & 3.62 & & \\
\cline { 2 - 3 } & seoska & 3.51 & & \\
\hline
\end{tabular}


Analizom odgovora učenika muškog pola $(4,07)$ i ženskog pola $(3,94)$ ne postoje statistički značajne razlike u konzumiranju kolača i slatkiša. U odgovorima učenika prvog razreda $(4,14)$, drugog razreda $(3,96)$, trećeg razreda $(4,03)$ i četvrtog razreda $(3,90)$ nema statistički značajnih razlika. U odgovorima učenika iz gradske sredine $(3,96)$, iz prigradske sredine $(3,96)$, i seoske sredine $(3,92)$ ne postoje statistički značajne razlike. (Tabela 8.)

Tabela 8. Odgovori učenika o konzumiranju kolača i slatkiša prema polu, razredu i sredini iz koje dolaze učenici

\begin{tabular}{|c|c|c|c|c|}
\hline \multirow{4}{*}{ Pol } & \multicolumn{4}{|c|}{ Koliko konzumirate kolača i slatkiša? } \\
\hline \multirow{4}{*}{ Razred } & male & Mean & KW(H) & KW(p) \\
\cline { 2 - 3 } & female & 4.07 & \multirow{2}{*}{1.434} & 0.231 \\
\cline { 2 - 3 } & 1. razred & 3.94 & \multirow{2}{*}{2.154} & \multirow{2}{*}{0.541} \\
\cline { 2 - 3 } & 2. razred & 3.14 & & \\
\cline { 2 - 3 } & 3. razred & 4.96 & \multirow{2}{*}{1.125} & \multirow{2}{*}{0.570} \\
\hline \multirow{3}{*}{ Sredina } & 4. razred & 3.90 & \\
\cline { 2 - 3 } & gradska & 3.96 & & \\
\cline { 2 - 3 } & prigradska & 3.96 & & \\
\hline
\end{tabular}

Analizom odgovora učenika muškog pola $(3,34)$ i ženskog pola $(3,29)$ postoje statistički značajne razlike u konzumiranju vode i voćnih sokova. U odgovorima učenika prvog razreda $(3,10)$, drugog razreda $(3,41)$, trećeg razreda $(3,29)$ i četvrtog razreda $(3,14)$ nema statistički značajnih razlika. U odgovorima učenika iz gradske sredine $(3,25)$, iz prigradske sredine $(3,32)$ i seoske sredine $(3,40)$ ne postoje statistički značajne razlike. Tabela 9.

Tabela 9. Odgovori učenika o konzumiranju vode i voćnih sokova prema polu, razredu i sredini iz koje dolaze učenici

\begin{tabular}{|c|c|c|c|c|}
\hline \multicolumn{5}{|c|}{ Koliko konzumirate vode i voćnih sokova? } \\
\hline \multirow{3}{*}{ Pol } & Pol & Mean & KW(H) & KW(p) \\
\hline \multirow{4}{*}{ Razred } & male & 3.34 & \multirow{2}{*}{0.270} & \multirow{2}{*}{0.603} \\
\cline { 2 - 3 } & female & 3.29 & & \\
\cline { 2 - 3 } & 1. razred & 3.10 & \multirow{2}{*}{3.272} & \multirow{2}{*}{0.352} \\
\cline { 2 - 3 } & 2. razred & 3.41 & \\
\cline { 2 - 3 } Sredina & 3. razred & 3.29 & \multirow{2}{*}{0.710} \\
\cline { 2 - 3 } & 4. razred & 3.14 & \\
\cline { 2 - 3 } & gradska & 3.25 & \\
\cline { 2 - 3 } & prigradska & 3.32 & & \\
\hline
\end{tabular}


Analizom odgovora učenika muškog pola $(3,91)$ i ženskog pola $(3,78)$ postoje statistički značajne razlike u konzumiranju energetskih i gaziranih pića. U odgovorima učenika prvog razreda $(4,06)$, drugog razreda $(3,82)$, trećeg razreda $(3,88)$ i četvrtog razreda $(3,62)$ nema statistički značajnih razlika. U odgovorima učenika iz gradske sredine $(3,83)$, iz prigradske sredine $(3,78)$, i seoske sredine $(3,92)$ ne postoje statistički značajne razlike. (Tabela 10.)

Tabela 10. Odgovori učenika o konzumiranju energetskih i gaziranih pića prema polu, razredu i sredini iz koje dolaze učenici

\begin{tabular}{|c|c|c|c|c|}
\hline \multicolumn{5}{|c|}{ Koliko konzumirate energetskih i gaziranih pića? } \\
\hline \multirow{3}{*}{ Pol } & Pol & Mean & KW(H) & \multirow{2}{*}{ KW(p) } \\
\hline \multirow{4}{*}{ Razred } & male & 3.91 & \multirow{2}{*}{0.510} & 0.475 \\
\cline { 2 - 3 } & female & 3.78 & & \multirow{2}{*}{0.215} \\
\cline { 2 - 3 } & 1. razred & 4.06 & \multirow{2}{*}{4.467} & \\
\cline { 2 - 3 } & 2. razred & 3.82 & \\
\hline \multirow{3}{*}{ Sredina } & 3. razred & 3.88 & \multirow{2}{*}{0.977} \\
\cline { 2 - 3 } & 4. razred & 3.62 & \\
\cline { 2 - 3 } & gradska & 3.83 & & \\
\cline { 2 - 3 } & prigradska & 3.78 & & \\
\hline
\end{tabular}

Na Slici 1 grafički su prikazane procentualne vrednosti svih učenika o navikama u ishrani svake ispitivane grupe namirnica.

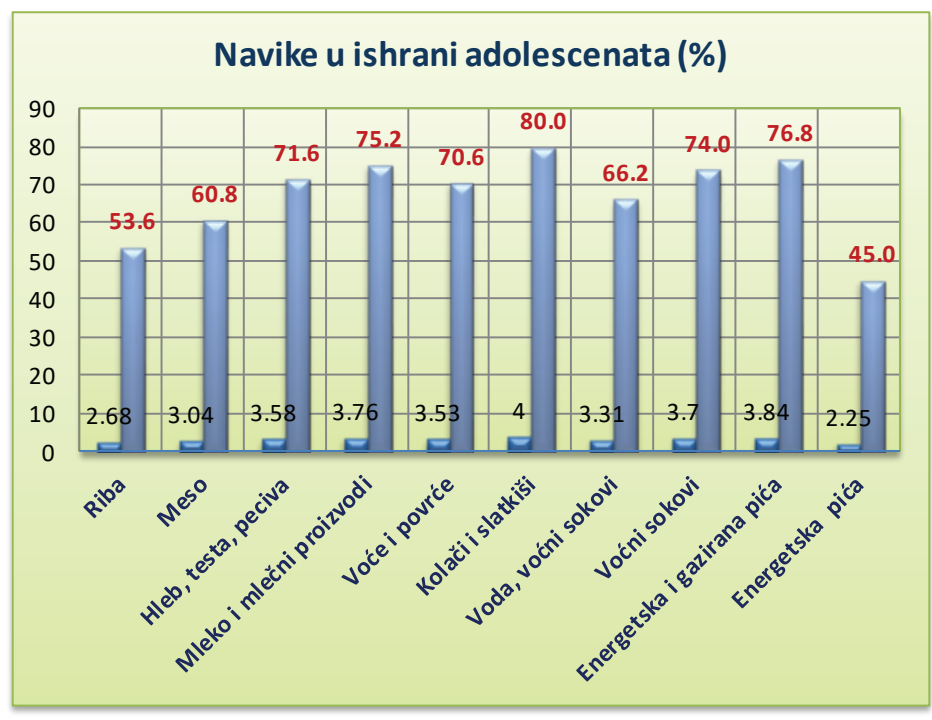

Slika 1. Navike u ishrani adolescenata po grupama ispitivanih namirnica 
Treća grupa pitanja odnosila se na način ishrane. Analizom odgovora učenika muškog pola $(3,73)$ i učenika ženskog pola $(3,61)$ utvrdili smo da ne postoje statistički značajne razlike u načinu ishrane u kući ili van. U odgovorima učenika prvog razreda $(3,85)$, drugog razreda $(3,69)$, trećeg razreda $(3,38)$ i četvrtog razreda $(3,71)$ nema statistički značajnih razlika. U odgovorima učenika iz gradske sredine $(3,72)$, iz prigradske sredine $(3,41)$, i seoske sredine $(3,94)$ postoje statistički značajne razlike. (Tabela 11.)

Tabela 11. Odgovori učenika o načinu ishrane prema polu, razredu i sredini iz koje dolaze učenici

\begin{tabular}{|c|c|c|c|c|}
\hline \multicolumn{5}{|c|}{ Da li se hranite više u kući nego van? } \\
\hline \multirow{3}{*}{ Pol } & Pol & Mean & KW(H) & \multirow{2}{*}{ KW(p) } \\
\hline \multirow{4}{*}{ Razred } & male & 3.73 & \multirow{3}{*}{0.536} & \multirow{2}{*}{0.215} \\
\cline { 2 - 3 } & female & 3.61 & \multirow{2}{*}{6.577} & \multirow{2}{*}{0.087} \\
& 1. razred & 3.85 & \\
\cline { 2 - 3 } & 2. razred & 3.69 & \\
\cline { 2 - 3 } Sredina & 3. razred & 3.38 & \multirow{2}{*}{6.266} & \multirow{2}{*}{0.044} \\
\cline { 2 - 3 } & 4. razred & 3.71 & \\
\hline & gradska & 3.72 & \\
\cline { 2 - 3 } & prigradska & 3.41 & & \\
\hline
\end{tabular}

Analizom odgovora učenika po pitanju postojanja zdravstvenih teškoća ili naslednih bolesti, kod učenika muškog pola $(1,59)$ i učenika ženskog pola $(1,68)$ ne postoje statistički značajne razlike. U odgovorima učenika prvog razreda $(1,68)$, drugog razreda $(1,73)$, trećeg razreda $(1,56)$ i četvrtog razreda $(1,64)$ nema statistički značajnih razlika. U odgovorima učenika iz gradske sredine $(1,73)$, iz prigradske sredine $(1,64)$ i seoske sredine $(1,52)$ ne postoje statistički značajne razlike. (Tabela 12.)

Tabela 12. Odgovori učenika po pitanju zdravstvenih teškoća ili naslednih bolesti prema polu, razredu i sredini iz koje dolaze učenici

\begin{tabular}{|c|c|c|c|c|}
\hline \multicolumn{5}{|c|}{ Da li imate zdravstvenih teškoća ili naslednih bolesti? } \\
\hline & Pol & Mean & $\mathrm{KW}(\mathrm{H})$ & $K W(p)$ \\
\hline \multirow{2}{*}{ Pol } & male & 1.59 & \multirow{2}{*}{0.739} & \multirow{2}{*}{0.390} \\
\hline & female & 1.68 & & \\
\hline \multirow{4}{*}{ Razred } & 1. razred & 1.73 & \multirow{4}{*}{0.453} & \multirow{4}{*}{0.929} \\
\hline & 2. razred & 1.56 & & \\
\hline & 3. razred & 1.65 & & \\
\hline & 4. razred & 1.64 & & \\
\hline \multirow{3}{*}{ Sredina } & gradska & 1.73 & \multirow{3}{*}{0.090} & \multirow{3}{*}{0.956} \\
\hline & prigradska & 1.64 & & \\
\hline & seoska & 1.52 & & \\
\hline
\end{tabular}


Analizom odgovora učenika po pitanju držanja dijeta između učenika muškog pola $(1,62)$ i učenika ženskog pola (2.04) postoje statistički značajne razlike, naime, učenici ženskog pola više drže dijete od učenika muškog pola. U odgovorima učenika prvog razreda $(2,04)$, drugog razreda $(1,80)$, trećeg razreda $(1,72)$ i četvrtog razreda $(1,87)$ nema statistički značajnih razlika. U odgovorima učenika iz gradske sredine $(1,87)$, iz prigradske sredine $(1,87)$, i seoske sredine $(1,77)$ ne postoje statistički značajne razlike. (Tabela 13.)

Tabela 13. Odgovori učenika o držanju dijeta prema polu, razredu i sredini iz koje dolaze učenici

\begin{tabular}{|c|c|c|c|c|}
\hline \multicolumn{5}{|c|}{ Da li ste nekada držali dijetu? } \\
\hline \multirow{3}{*}{ Pol } & Pol & Mean & KW(H) & \multirow{2}{*}{ KW(p) } \\
\hline \multirow{4}{*}{ Razred } & male & 1.62 & \multirow{2}{*}{10.436} & \multirow{2}{*}{0.001} \\
\cline { 2 - 3 } & female & 2.04 & & \\
\cline { 2 - 3 } & 1. razred & 2.04 & \multirow{2}{*}{3.713} & \multirow{2}{*}{0.294} \\
\cline { 2 - 3 } & 2. razred & 1.80 & \\
\cline { 2 - 3 } Sredina & 3. razred & 1.84 & \multirow{2}{*}{0.771} & 0.680 \\
\cline { 2 - 3 } & 4. razred & 1.72 & \\
\cline { 2 - 3 } & gradska & 1.87 & & \\
\hline
\end{tabular}

Analizom odgovora učenika po pitanju uticaja dijeta na zdravlje između učenika muškog pola $(2,54)$ i učenika ženskog pola $(2,55)$ ne postoje statistički značajne razlike. U odgovorima učenika prvog razreda $(2,56)$, drugog razreda $(2,61)$, trećeg razreda $(2,42)$ i četvrtog razreda $(2,58)$ nema statistički značajnih razlika. U odgovorima učenika iz gradske sredine $(2,53)$, iz prigradske sredine $(2,48)$ i seoske sredine $(2,67)$ ne postoje statistički značajne razlike. (Tabela 14.)

Tabela 14. Odgovori učenika o uticaju dijeta na zdravlje prema polu, razredu i sredini iz koje dolaze učenici

\begin{tabular}{|c|c|c|c|c|}
\hline \multicolumn{5}{|c|}{ Da li smatrate da dijeta utiče na zdravlje? } \\
\hline & Pol & Mean & $\mathrm{KW}(\mathrm{H})$ & KW(p) \\
\hline \multirow{2}{*}{ Pol } & male & 2.54 & \multirow{2}{*}{0.004} & \multirow{2}{*}{0.949} \\
\hline & female & 2.55 & & \\
\hline \multirow{4}{*}{ Razred } & 1. razred & 2.56 & \multirow{4}{*}{4.467} & \multirow{4}{*}{0.215} \\
\hline & 2. razred & 2.61 & & \\
\hline & 3. razred & 2.42 & & \\
\hline & 4. razred & 2.58 & & \\
\hline \multirow{3}{*}{ Sredina } & gradska & 2.53 & \multirow{3}{*}{4.916} & \multirow{3}{*}{0.086} \\
\hline & prigradska & 2.48 & & \\
\hline & seoska & 2.67 & & \\
\hline
\end{tabular}


Analizom odgovora učenika po pitanju da li se pravilnom ishranom mogu ublažiti ili sprečiti neke bolesti, kao što su dijabetes, holesterol i druge, između učenika muškog pola $(4,29)$ i učenika ženskog pola $(3,95)$ postoje statistički značajne razlike, naime, učenici muškog pola su svesniji da se zdravom hranom mogu izbeći određene bolesti. U odgovorima učenika prvog razreda $(4,46)$, drugog razreda $(4,10)$, trećeg razreda $(3,77) \mathrm{i}$ četvrtog razreda $(4,12)$ postoje statistički značajne razlike. U odgovorima učenika iz gradske sredine $(4,10)$, iz prigradske sredine $(4,05)$ i seoske sredine $(4,20)$ ne postoje statistički značajne razlike. (Tabela 15.)

Tabela 15. Odgovori učenika o načinu ishrane prema polu, razredu i sredini iz koje dolaze učenici

\begin{tabular}{|c|c|c|c|c|}
\hline & Pol & Mean & $\mathrm{KW}(\mathrm{H})$ & $\mathrm{KW}(\mathrm{p})$ \\
\hline \multirow{2}{*}{ Pol } & male & 4.29 & \multirow{2}{*}{6.985} & \multirow[b]{2}{*}{0.008} \\
\hline & female & 3.95 & & \\
\hline \multirow{4}{*}{ Razred } & 1. razred & 4.46 & \multirow{4}{*}{11.686} & \multirow{4}{*}{0.009} \\
\hline & 2. razred & 4.10 & & \\
\hline & 3. razred & 3.77 & & \\
\hline & 4. razred & 4.12 & & \\
\hline \multirow{3}{*}{ Sredina } & gradska & 4.10 & \multirow{3}{*}{0.396} & \multirow{3}{*}{0.821} \\
\hline & prigradska & 4.05 & & \\
\hline & seoska & 4.20 & & \\
\hline
\end{tabular}

Analizom odgovora učenika po pitanju redovnog doručka između učenika muškog pola $(3,82)$ i učenika ženskog pola $(3,60)$ postoje statistički značajne razlike, naime, učenici muškog pola su svesniji da se zdravom hranom mogu izbeći određene bolesti. U odgovorima učenika prvog razreda $(3,74)$, drugog razreda $(3,82)$, trećeg razreda $(3.80)$ i četvrtog razreda $(3,99)$ postoje statistički značajne razlike. U odgovorima učenika iz gradske sredine $(3,93)$, iz prigradske sredine $(3,82)$, i seoske sredine $(3,60)$ ne postoje statistički značajne razlike. (Tabela 16.)

Tabela 16. Odgovori učenika po pitanju redovnog doručka prema polu, razredu i sredini iz koje dolaze učenici

\begin{tabular}{|c|c|c|c|c|}
\hline \multicolumn{5}{|c|}{ Da li redovno doručkujete? } \\
\hline & Pol & Mean & $\mathrm{KW}(\mathrm{H})$ & KW(p) \\
\hline \multirow{2}{*}{ Pol } & male & 3.99 & \multirow{2}{*}{6.771} & \multirow{2}{*}{0.009} \\
\hline & female & 3.63 & & \\
\hline \multirow{4}{*}{ Razred } & 1. razred & 3.74 & \multirow{4}{*}{0.163} & \multirow{4}{*}{0.983} \\
\hline & 2. razred & 3.82 & & \\
\hline & 3. razred & 3.80 & & \\
\hline & 4. razred & 3.81 & & \\
\hline \multirow{3}{*}{ Sredina } & gradska & 3.93 & \multirow{3}{*}{3.064} & \multirow{3}{*}{0.216} \\
\hline & prigradska & 3.82 & & \\
\hline & seoska & 3.60 & & \\
\hline
\end{tabular}


Drugi deo istraživanja odnosio se na ispitivanje rizika za nastanak dijabetesa tip 2, korišćenjem standardizovanog upitnika, koji su učenici dobrovoljno popunjavali. Online upitnik je popunilo ukupno 111 učenika, 48 (43,2\%) muškog pola i $63(56,7 \%)$ ženskog pola i nema statistički značajnih razlika u odnosu muških i ženskih ispitanika u uzorku na rizik od nastanka dijabetesa tip 2. Kod učenika muškog pola u niskom riziku je $79,2 \%$ učenika, $14,5 \%$ u lako povišenom, $2,1 \%$ učenika ima umeren rizik i $4,2 \%$ visok rizik od nastanka dijabetesa tip 2 , dok nema učenika sa veoma visokim rizikom. Kod učenika ženskog pola u niskom riziku je 76,2\% učenika, 15,9\% u lako povišenom, 3,2\% učenika ima umeren rizik i 4,7\% visok rizik od nastanka dijabetesa tip 2, dok nema učenika sa veoma visokim rizikom. (Tabela 17.)

Tabela 17. Rezultati ispitivanja rizika učenika na nastanak dijabetesa tip 2 prema polu

\begin{tabular}{|c|c|c|c|c|}
\hline Pol & Procenat učenika & Rizik & $\mathrm{KW}(\mathrm{H})$ & $\mathrm{KW}(\mathrm{p})$ \\
\hline \multirow{5}{*}{$\begin{array}{c}\text { male } \\
(48) \\
(43.2 \%)\end{array}$} & 79.2 & Nizak & \multirow{10}{*}{2.027} & \multirow{10}{*}{0.155} \\
\hline & 14.5 & Lako povišen & & \\
\hline & 2.1 & Umeren & & \\
\hline & 4.2 & Visok & & \\
\hline & 0.0 & Veoma visok & & \\
\hline \multirow{5}{*}{$\begin{array}{c}\text { female } \\
(63) \\
(56.7 \%)\end{array}$} & 76.2 & Nizak & & \\
\hline & 15.9 & Lako povišen & & \\
\hline & 3.2 & Umeren & & \\
\hline & 4.7 & Visok & & \\
\hline & 0.0 & Veoma visok & & \\
\hline
\end{tabular}

Izmerene vrednosti indeksa telesne mase BMI (Body mass index) veće od 30 nalaze se kod $6,2 \%$ učenika muškog pola i $7,9 \%$ učenika ženskog pola, vrednosti između 25 i 30 nalazi, se 14,6\% učenika muškog pola i $22,2 \%$ ženskog pola, a sa manjim od 25 nalazi se velika većina $79,2 \%$ učenika muškog pola i $69,9 \%$ učenika ženskog pola. Izmerene vrednosti obima struka veće od 102 nalaze se kod 6,2\% učenika muškog pola, vrednosti između 94 i 102 nalazi se kod 14,6\% učenika, a sa manjim od 94 nalazi se velika većina 79,2\% učenika. Izmerene vrednosti obima struka veće od 88 nalaze se kod 7,9\% učenika ženskog pola, vrednosti između 80 i 88 nalazi se kod 7,9\% učenika ženskog pola, a sa manjim od 80 nalazi se velika većina 79,4\% učenika. Nema statistički značajnih razlika u vrednostima BMI i izmerenih vrednosti obima struka kod učenika muškog i ženskog pola. (Tabela 18.)

Tabela 18. Procenat učenika BMI i vrednosti obima struka prema polu

\begin{tabular}{|c|c|c|c|c|c|c|}
\hline \multirow{2}{*}{} & $\begin{array}{c}\text { BMI } \\
(\mathbf{\%})\end{array}$ & \multicolumn{2}{|c|}{ Bodovi } & $\begin{array}{c}\text { Obim struka } \\
(\%)\end{array}$ & \multicolumn{2}{c|}{ Bodovi } \\
\hline \multirow{3}{*}{ male } & 6.2 & $>30$ & 3 & 6.2 & $>102$ & 4 \\
\cline { 2 - 8 } & 14.6 & $25-30$ & 1 & 14.6 & $94-102$ & 3 \\
\cline { 2 - 8 } & 79.2 & $<25$ & 0 & 79.2 & $<94$ & 0 \\
\hline
\end{tabular}




\begin{tabular}{|c|c|c|c|c|c|c|}
\hline \multirow{3}{*}{ female } & 7.9 & $>30$ & 3 & 7.9 & $>88$ & 4 \\
\cline { 2 - 7 } & 22.2 & $25-30$ & 1 & 12.7 & $80-88$ & 3 \\
\cline { 2 - 7 } & 69.9 & $<25$ & 0 & 79.4 & $<80$ & 0 \\
\hline & $\mathrm{KW}(\mathrm{H})$ & $\mathrm{KW}(\mathrm{p})$ & & $\mathrm{KW}(\mathrm{H})$ & $\mathrm{KW}(\mathrm{p})$ & \\
\hline & 0.318 & 0.573 & & 0.000 & 0.983 & \\
\hline
\end{tabular}

Procenat učenika koji su koristili antihipertenzivne lekove iznosi kod muškog pola $4,2 \%$, kod ženskog pola $3,2 \%$, a onih koji nisu koristili antihipertenzivne lekove kod muškog pola iznosi $95,8 \%$, kod ženskog pola iznosi $96,8 \%$. Procenat učenika kod kojih je izmeren povišen šećer iznosi kod muškog pola 4,2\%, kod ženskog pola $4.8 \%$, a onih kojima nije izmeren povišen šećer kod muškog pola iznosi $95,8 \%$, kod ženskog pola iznosi $95,2 \%$. Nema statistički značajnih razlika u procentu učenika koji koriste antihipertenzivne lekove, ni u procentu učenika kod kojih je izmeren povišen šećer zavisno od muškog i ženskog pola. (Tabela 19.)

Tabela 19. Procenat učenika koji koriste antihipertenzivne lekove i učenika kojima je izmerena vrednost šećera prema polu,

\begin{tabular}{|c|c|c|c|c|c|c|}
\hline & $\begin{array}{c}\text { Antihipertenzivni } \\
\text { lekovi } \\
(\%)\end{array}$ & \multicolumn{2}{|c|}{ Bodovi } & \multicolumn{2}{c|}{$\begin{array}{c}\text { Vrednosti šećera } \\
(\%)\end{array}$} & \multicolumn{2}{c|}{ Bodovi } \\
\hline \multirow{2}{*}{ male } & 4.2 & $\mathrm{Da}$ & 2 & 4.2 & $\mathrm{Da}$ & 5 \\
\cline { 2 - 7 } female & 95.8 & $\mathrm{Ne}$ & 0 & 95.8 & $\mathrm{Ne}$ & 0 \\
\cline { 2 - 7 } & 3.2 & $\mathrm{Da}$ & 2 & 4.8 & $\mathrm{Da}$ & 5 \\
\hline & 96.8 & $\mathrm{Ne}$ & 0 & 95.2 & $\mathrm{Ne}$ & 0 \\
\hline & $\mathrm{KW}(\mathrm{H})$ & $\mathrm{KW}(\mathrm{p})$ & & $\mathrm{KW}(\mathrm{H})$ & $\mathrm{KW}(\mathrm{p})$ & \\
\hline & 0.022 & 0.881 & & 0.076 & 0.782 & \\
\hline
\end{tabular}

Najveći uticaj naslednih faktora za rizik za nastanak dijabetesa tip 2 je kod učenika muškog pola od članova najuže porodice i iznosi $16,7 \%$, a kod učenika ženskog pola je 7,9\%. Uticaj naslednih faktora od članova šire porodice je kod učenika muškog pola veći i iznosi $1,8 \%$, a kod učenika ženskog pola $12,7 \%$. Bez uticaja naslednih faktora je kod $64,5 \%$ učenika muškog pola i kod 79,4\% učenika ženskog pola. (Tabela 20.)

Tabela 20. Procenat učenika sa naslednim rizicima za nastanak dijabetesa tip 2 prema polu

\begin{tabular}{|c|c|c|c|c|c|}
\hline \multirow{2}{*}{ male } & $\begin{array}{c}\text { Nasledni faktori } \\
(\%)\end{array}$ & \multicolumn{2}{|c|}{ Bodovi } & \multirow{2}{*}{ KW(H) } & \multirow{2}{*}{ KW(p) } \\
\hline \multirow{3}{*}{ female } & 16.7 & $\mathrm{Da}$ (uža porodica) & 5 & & \\
\cline { 2 - 4 } & 18.8 & $\mathrm{Da}$ (rodbina) & 3 & & \\
\cline { 2 - 4 } & 64.5 & Ne & 0 & & \multirow{2}{*}{3.173} \\
\cline { 2 - 4 } & 7.9 & $\mathrm{Da}$ (uža porodica) & 5 & \multirow{2}{*}{0.075} \\
\hline
\end{tabular}




\section{Zaključak}

Analizirajući navike u ishrani adolescenata može se zaključiti da se one ne razlikuju previše u zavisnosti od pola učenika. (15) Manje razlike između polova postoje u navikama kod određenih namirnica. Iz prethodnih analiza može se zaključiti da učenici muškog pola konzumiraju više mesa za oko 7,5\% u odnosu na učenike ženskog pola. Takođe, ženski učenici za $8,3 \%$ više drže dijete nego muški učenici. Učenici muškog pola za $7,2 \%$ više njih doručkuje redovno u odnosu na učenike ženskog pola. Posmatrano po sredini iz koje dolaze, ribu najviše konzumiraju učenici iz prigradske sredine za $8 \%$ više nego iz gradske i seoske sredine. Voće i povrće za oko $2,5 \%$ više konzumiraju učenici iz prigradske sredine nego iz gradske i seoske. Najveći procenat $10 \%$ učenika iz seoske sredine konzumira hranu kod kuće, u odnosu na učenike iz gradske i prigradske sredine. Dok se razlike u stavovima po pitanju uticaja pravilne ishrane na nastajanje hroničnih nezaraznih bolesti razlikuje i po polu i po sredini iz koje dolaze (16), (17). Naša uvedena pretpostavka nije održiva, pa prihvatamo alternativnu hipotezu prvoj hipotezi $\mathrm{H} 1$.

Uopšteno, navike u ishrani adolescenata nisu najbolje iz razloga što u velikom procentu konzumiraju: kolače i slatkiše $80 \%$, energetska i gazirana pića $76,8 \%$, hleb, testa i peciva $71,6 \%$. Slika 1. Rezultati standardizovanog upitnika pokazuju da je $4,2 \%$ učenika muškog pola i $4,7 \%$ učenika ženskog pola u visokom riziku za nastanak dijabetesa tip 2 (18). U umerenom riziku je 2,1\% učenika muškog i 3,2\% učenika ženskog pola. U lako povišenom riziku je $14,5 \%$ učenika muškog pola i $15,9 \%$ učenika ženskog pola. (Tabela 17.)

Uzimajući u obzir navike u ishrani i trenutne rezultate procene rizika za nastanak dijabetesa kod učenika uzrasta od 14 do 18 godina, neophodno je preventivno delovanje, (19) kako bi se rizik smanjio i što je više moguće ublažio. (14) Možemo potvrditi uvedenu pretpostavku da je procenat rizika za nastanak dijabetesa tip 2 i kod muških i kod ženskih učenika manji od $15 \%$, i da se uvedena hipoteza $\mathrm{H} 2$ može prihvatiti.

Potrebno je predložiti učenicima koji su u visokom i umerenom riziku da urade OGTT test, kako bi se otklonile ili potvrdile navedene sumnje vezane za dijabetes tip 2 (20), (21). Potrebno je da se svi učenici upoznaju sa posledicama nepravilne ishrane i bolestima koje mogu nastati.

\section{Reference}

1. M. Dokić, M. Jevtić, D. Balać, Prevencija dijabetesa melitusa tipa 2 kod dece i adolescenata, Medicinski glasnik, 1452-09231141050D, 2011.

2. Ž. Lalić, K. Rašković, Procena rizika za dijabetes melitus tip 2 kod zdravstvenih radnika, Opšta medicina, UDC 616.379-008.64-05, 716(3-4); 138-142, 2010. 
3. Incidencija i mortalitet od dijabetesa u Srbiji, Institut za javno zdravlje „Milan Jovanović Batut, 2017.

4. MedicineWorld.Org - Endocrinology-Type 2 diabetes, Your gateway to information on type 2 diabetes http://www.medicineworld.org/medicine/endocrinology/type2diabetes. html

5. M. Dumić, A. Š. Uroić, Šećerna bolest u adolescenata, Klinika za pedijatriju Medicinskog fakulteta Sveučilišta u Zagrebu, KBC Zagreb, MEDICUS 2010, Vol. 19, No. 1, 27-34.

6. R. Vuković, D. Zdravković. Učestalost poremećaja u regulaciji glukoze kod gojazne dece i adolescenata u Srbiji. Medicinski glasnik Specijalna bolnica za bolesti štitaste žlezde i bolesti metabolizma, Zlatibor 2012; 17: 92-105.

7. G. Švonja-Parezanović, B. Perić-Prkosovački, Uhranjenost i navike u ishrani mladih. PONS Med Čas 2014; 11: 48-52.

8. G. Bukara-Radujković, D. Zdravković, Determinante gojaznosti kod dece i adolescenata. Srp Arh Celok Lek 2008; 136: 22-7.

9. About BMI for Children and Teens. Atalanta: Centers for Disease Control and Prevention, 2015. http://www.cdc.gov/healthyweight/assessing/bmi/childrens_bmi/about_childrens_ bmi.html

10. SR. Daniels, DK. Arnett, RH. Eckel, et al. Overweight in children and adolescents: pathophysiology, consequences, prevention, and treatment. Circulation 2005; 111: 1999-2002.

11. The Diabetes Control and Complications Trial Research Group. The absence of aglycaemic treshold for the development of long-term complications: the perspective of DCCT. Diabetes 1996; 45: 1289-98.

12. SPSS Statistical, dostupno na: https://www.ibm.com/products/spss-statistics.

13. Rad u SPSS-u, dostupno na: http://stat.uns.ac.rs/LLLprogramme/NP/TeachingMaterial/ Uputstvo.pdf

14. I. Jevtović, Medicinska statistika. Kragujevac: Medicinski fakultet, 2008.

15. American Diabetes Association: Type 2 diabetes in children and adolescents. American Diabetes Association. Pediatrics 2000; 105: 671-80.6. F. Chiarellif, C. Giannini, A. Mohn A., Growth, growth factors and diabetes. Eur J Endocrinol. 2004; 151 (Suppl 3): U109-17.

16. J. Lebl, E. Schober, T. Zidek et al., Growth data in large series of 587 children and adolescents with type 1 diabetes mellitus. Endocr Regul 2003; 37: 153-61.

17. Cl. Cacerinini, RM. Williams, DB, Dunger, Metabolic impact of puberty on the course of type 1 diabetes. Diabetes Metab 2001; 27: S19-25.

18. Y. Xin, A. Davies, L. McCombie, A. Briggs, CM Messow, E. Grieve, et al., Type 2 diabetes remission: economic evaluation of the DiRECT/Counterweight-Plus weight management programme within a primary care randomized controlled trial, Med. 2019. doi: $10.1111 /$ dme.13981

19. Z. Liu, C. Fu, W. Wang, B.Xu, Prevalence of chronic complications of type 2 diabetes mellitus in outpatients - a crosssectional hospital based survey in urban China. Health Qual Life Outcomes 2010; 8: 62. 
20. WC. Chumlea, CM. Schubert, AF. Roche et al, Age at menarche and racial comparisons in US girls. Pediatrics. 2003; 111: 110-3.

21. B. Anderson, J. Ho, J. Brackett, D. Finkelstein, L. Laffel, Parental involvement in diabetes management tasks: relationships to blood glucose monitoring adherence and metabolic control in young adolescents with insulin-dependent diabetes mellitus. J Pediatr 1997; 130: 257-65. 
Igor Lukić1, Nevena Ranković2, Dragica Ranković ${ }^{3}$

\title{
RISK ASSESSMENT FOR DIABETES TYPE 2 CONDITIONS FOR NATURE IN NUTRITION IN ADOLESCENTS
}

\begin{abstract}
Apstract: This paper will present the results of a study on dietary habits in adolescents. The high school or adolescent era is a time of great physical and psychological changes, which cause instability and oscillations in the mood and behavior of high school students. Results obtained by interviewing secondary school students about eating habits and results obtained using a standardized questionnaire for the risk of type 2 diabetes were analyzed using a reliable statistical tool IBM SPSS Statistical, which offers a range of reliable analyzes and statistical tests. Previous research has shown that for each person with type 2 diabetes, one person finds out who does not know it. Discovery of pre-diabetes, in new potential patients, is necessary at the earliest age, when a number of factors affect lifestyles, such as irregular nutrition and obesity, physical inactivity, stress, and others become important for the development of this disease. Detection of risk levels in potential patients is important for both the individual and public health, and everyday clinical practice. After determining the degree of risk for a particular sample, a set of measures for a particular adolescent population will be recommended, so that the disease does not occur, or its onset will move for a later period of life.
\end{abstract}

Keywords: nutrition, diabetes type 2, adolescente, risk factors.

\footnotetext{
Engleska verzija ovog rada objavljena je u časopisu Medicinski glasnik, broj 79 . Igor Lukić, PhD student, Faculty of Medicine, Kragujevac.

2 Nevena Ranković, Assistant at the Department of Computer Science, Faculty of Sciences, Novi Sad.
}

Dragica Ranković, Medical School „Dr Miša Pantić”, Valjevo. 


\section{Introduction}

Type 2 diabetes is an insulin-independent type of diabetes, in which insulin secretion is reduced (1). It can occur at any age, but most commonly in obese people. In the last decade, with significant numbers of adolescents, there is extreme obesity, mostly caused by improper nutrition, insufficient physical activity, stress, etc. (2) Along with the increase in obesity, there is an increase in type 2 diabetes, heart disease, stroke, diabetes retinopathy, which has an effect on vision, kidney failure, resulting in dialysis, poor circulation in the most commonly lower extremities, which can be caused by amputations and many other diseases (3), (4), (5).

Type 2 diabetes, which previously had the highest incidence in the elderly, begins to increase exponentially and even in children, especially in the period of puberty or adolescence (6), (7). In the last decade, with a significant number of adolescents, there is extreme obesity, mainly caused by irregular nutrition, insufficient physical activity, stress, etc. (8) In addition to the increase in obesity, type 2 diabetes also occurs (9), (10). Many studies in the country and abroad show that by reducing the intake of certain foods, weight can be reduced, and hence the risk of this disease (11), (5).

\section{Structure of the sample}

A total of 318 secondary school students from the Kolubara district participated in the research that will be presented in this paper. The structure of the sample consisted of 145 (45.6\%) male students and 173 (54.4\%) female students. Observed by the classes currently taught, the structure of students consists of: $71(22.3 \%)$ students of the first year, $89(28.0 \%)$ students of the second year, 79 (24.8\%) students of the third year and $79(24.8 \%)$ students of the fourth year. The center from which students come from: the urban environment 113 (35.5) students, suburban 114 (35.8\%) students and the rural environment 91 (28.7) pupils. There are no statistically significant differences in the gender, class, or environment from which they come (Table 1).

Table 1. Student sample structure

\begin{tabular}{|c|c|c|c|c|c|}
\hline \multicolumn{6}{|c|}{ Student sample structure } \\
\hline & & $\begin{array}{c}\text { Frequency } \\
\%\end{array}$ & Percent & CS & $\mathrm{CS}(\mathrm{p})$ \\
\hline \multirow{2}{*}{ Gender } & male & 145 & 45.6 & \multirow{2}{*}{2.465} & \multirow[b]{2}{*}{0.116} \\
\hline & female & 173 & 54.4 & & \\
\hline \multirow{4}{*}{ Class } & 1. class & 71 & 22.3 & \multirow{4}{*}{2.050} & \multirow{4}{*}{0.562} \\
\hline & 2. class & 89 & 28.0 & & \\
\hline & 3. class & 79 & 24.8 & & \\
\hline & 4. class & 79 & 24.8 & & \\
\hline
\end{tabular}




\begin{tabular}{|c|c|c|c|c|c|}
\hline \multicolumn{5}{|c|}{ Student sample structure } \\
\hline \multirow{3}{*}{ Environment } & $\begin{array}{c}\text { Frequency } \\
\text { \% }\end{array}$ & Percent & \multirow{2}{*}{ CS } & \multirow{2}{*}{ CS(p) } \\
\hline & urban & 113 & 35.5 & & \\
\cline { 2 - 4 } & suburban & 114 & 35.8 & \multirow{2}{*}{3.489} & \multirow{2}{*}{0.175} \\
\cline { 2 - 4 } & rural & 91 & 28.7 & & \\
\hline
\end{tabular}

\section{Subject research}

In the first part of the study, students completed an anonymous questionnaire, which discusses their eating habits and the consumption of certain foods and beverages. The first part of the questionnaire, besides basic information such as gender, the class that they currently attend and the environment from which they come, contains a question about their assessment, opinion on the regularity of their nutrition. In the second group of questions, the students evaluated the average consumption of these types of foods such as fish, meat, milk and dairy products, bread, pastry and pastry, fruits, vegetables, cakes, sweets, water, fruit juices, energy, and aerated drinks. The third group of questions was issues related to the existence of health problems or hereditary diseases, keeping diets, their opinions and attitudes about diet, whether they necessarily have breakfast and generally affect food on health(6).

The second part of the study looked at the risk of type 2 diabetes. In a study of 318 students, 111 students volunteered to fill in an online standardized questionnaire, $48(43.2 \%)$ male students and $63(56.7 \%)$ female students. Since most students do not know the BMI value, a short online questionnaire was first made for calculating it, from which it is precisely possible to get the exact value. The standardized questionnaire for the type 2 diabetes risk contains 8 questions that students who want to answer can ask. The "pol" option is added to it, in order to compare student responses according to this criterion. The sum of the points obtained from the response provides a risk assessment of the onset of diabetes type 2 (7).

\section{Methodological remarks}

The results obtained using the questionnaire were analyzed using a reliable statistical tool IBM SPSS Statistical, which offers a range of reliable analyzes and statistical tests. Students' responses were on the 5-point Likert scale: (1 means very bad, 2 means bad, 3 means satisfactory, 4 means good, 5 is very good), Kruskal Wallis's H Test KW (H) and its significance KW (p) was used for this type of questions. To analyze the answer questions Yes/Neutral/No, the Chi-Square test (CS) and its significance CS (p) was used. For the analysis of the obtained results in the online 
test for the risk of diabetes type 2 were used: Mean and One-Way ANOVA Test for comparing the answers of male and female students. (12), (13), (14).

Research hypotheses:

H1: In adolescents aged 14 to 18 years, there are no statistically significant differences in consuming different foods by gender, age, or environment in which live.

H2: Small percentage (less than $15 \%$ ) of adolescents has a risk of diabetes type 2, observed by sex of respondents.

\section{Analysis of the obtained results}

The students gave their opinion on their own nutrition to the first question asked. $12.7 \%$ of male students believe that it is properly fed, the vast majority of $69.0 \%$ of pupils are properly fed, while $18.3 \%$ think it is fed incorrectly. $12.5 \%$ of female students think that it is properly fed, the vast majority of $78.5 \%$ of students are fed properly, while $9.0 \%$ think that they are feeding incorrectly. There are no statistically significant differences in students' responses to gender (Table 2).

Table 2. Students' opinions about their nutrition by gender, class, and environment from which they come

\begin{tabular}{|c|c|c|c|c|c|c|}
\hline \multicolumn{7}{|c|}{ Students' opinions about their nutrition by gender, class, and environment from which they come } \\
\hline & & Yes $\%$ & Neutral \% & № $\%$ & $\mathrm{KW}(\mathrm{H})$ & $\mathrm{KW}(\mathrm{p})$ \\
\hline \multirow{2}{*}{ Gender } & male & 12.7 & 69.0 & 18.3 & \multirow{2}{*}{2.538} & \multirow[b]{2}{*}{0.111} \\
\hline & female & 12.5 & 78.5 & 9.0 & & \\
\hline \multirow{4}{*}{ Class } & 1. class & 11.3 & 70.4 & 18.3 & \multirow{4}{*}{3.376} & \multirow{4}{*}{0.337} \\
\hline & 2. class & 20.9 & 65.1 & 14.0 & & \\
\hline & 3. class & 9.0 & 82.0 & 9.0 & & \\
\hline & 4. class & 8.0 & 80.0 & 12.0 & & \\
\hline \multirow{3}{*}{ Environment } & urban & 13.7 & 75.2 & 11.1 & \multirow{3}{*}{0.810} & \multirow{3}{*}{0.667} \\
\hline & suburban & 12.7 & 72.7 & 14.6 & & \\
\hline & rural & 10.0 & 74.4 & 14.6 & & \\
\hline
\end{tabular}


First-class students, total of $11.3 \%$ think that it is properly fed, partly properly fed by a large majority of $70.4 \%$ of students, while $18.3 \%$ think it is fed incorrectly. Second-class students $20.9 \%$ think that they are properly fed, the vast majority of $65.1 \%$ of students are fed partly properly, while $14.0 \%$ think that they are feeding incorrectly. Third-class students, total of $9.0 \%$ believe that they are properly fed, the vast majority of $82.0 \%$ of students are fed partly properly, while $9.0 \%$ think that they are feeding incorrectly. Students of the fourth class, total od $8.0 \%$ believe that it is properly fed, the vast majority of $80.0 \%$ of students are partially properly fed, while $12.0 \%$ think that they are feeding incorrectly. There are no statistically significant differences in pupils' responses to gender (Table 2).

Students from the urban environment, $13.7 \%$ of them think that they are properly fed, the vast majority of $75.2 \%$ of the students are partially properly fed, while $11.1 \%$ think that they are feeding incorrectly. About $12.7 \%$ of students in the suburban environment think that the majority of $72.7 \%$ of students are properly fed, while $14.6 \%$ believe that they are fed incorrectly. Around $10.0 \%$ of rural school students think that they are properly fed, the vast majority of $74.4 \%$ of students are fed partly properly, while $14.6 \%$ think that they are feeding incorrectly. There are no statistically significant differences in students' responses to gender (Table 2).

The second part of the questionnaire refers to students' habits in consuming certain groups of foods. By analyzing the responses of male (2.71) and female (2.66) students, there are no statistically significant differences in the consumption of fish and fish products. There are no statistically significant differences in the answers of the students of the first class (2.71), the second class(2.60), the third class (2.75) and the fourth class (2.68). In the answers from students from the urban environment (2.54), from the suburban environment (2.93), and the rural environment (2.53) there are statistically significant differences (Table 3 ).

Table 3. Answers of students about consuming fish and fish products by gender, class, and environment from which students come

\begin{tabular}{|c|c|c|c|c|}
\hline \multicolumn{5}{|c|}{ How much do you consume fish and fish products? } \\
\hline & & Mean & $\mathrm{KW}(\mathrm{H})$ & KW(p) \\
\hline \multirow[b]{2}{*}{ Gender } & male & 2.71 & \multirow[b]{2}{*}{0.252} & \multirow[b]{2}{*}{0.615} \\
\hline & female & 2.66 & & \\
\hline \multirow{4}{*}{ Class } & 1. class & 2.71 & \multirow{4}{*}{1.182} & \multirow{4}{*}{0.757} \\
\hline & 2. class & 2.60 & & \\
\hline & 3. class & 2.75 & & \\
\hline & 4. class & 2.68 & & \\
\hline
\end{tabular}




\begin{tabular}{|c|c|c|c|c|}
\hline \multirow{3}{*}{ Environment } & urban & 2.54 & \multirow{2}{*}{} \\
\cline { 2 - 3 } & suburban & 2.93 & \multirow{2}{*}{9.787} & $\mathbf{0 . 0 0 7}$ \\
\cline { 2 - 3 } & rural & 2.53 & & \\
\hline
\end{tabular}

By analyzing the answers of male students (3.24) and female students (2.87), there are statistically significant differences in the consumption of meat and meat products. In the answers of the students of the first class (3.01), the second class (2.94), the third class (3.16) and the fourth class (3.04) there are no statistically significant differences. In the answers of students from the urban environment (3.08), there are no statistically significant differences from the suburban environment (2.99) and the rural environment (3.04) (Table 4).

Table 4. Answers of students about consuming meat and meat products by gender, class, and environment from which students come

\begin{tabular}{|c|c|c|c|c|}
\hline \multicolumn{5}{|c|}{ How much do you consume meat and meat products? } \\
\hline & & Mean & $\mathrm{KW}(\mathrm{H})$ & KW(p) \\
\hline \multirow{2}{*}{ Gender } & male & 3.24 & \multirow[b]{2}{*}{9.667} & \multirow[b]{2}{*}{0.002} \\
\hline & female & 2.87 & & \\
\hline \multirow{4}{*}{ Class } & 1. class & 3.01 & \multirow{4}{*}{2.410} & \multirow{4}{*}{0.492} \\
\hline & 2. class & 2.94 & & \\
\hline & 3. class & 3.16 & & \\
\hline & 4. class & 3.04 & & \\
\hline \multirow{3}{*}{ Environment } & urban & 3.08 & \multirow{3}{*}{0.211} & \multirow{3}{*}{0.900} \\
\hline & suburban & 2.99 & & \\
\hline & rural & 3.04 & & \\
\hline
\end{tabular}

By analyzing the answers of male students (3.74) and female students (3.78), there are no statistically significant differences in the consumption of milk and dairy products. In the answers of students of the first class (3.80), second class (3.74), third class (3.85) and fourth class (3.67) there are no statistically significant differences. There are no statistically significant differences in the answers of students from the urban environment (3.79), from the suburban environment (3.68), and the rural environment (3.85). (Table 5). 
Table 5. Answers of students about consuming milk and dairy products according to the gender, class and environment from which students come

\begin{tabular}{|c|c|c|c|c|}
\hline \multicolumn{5}{|c|}{ How much do you consume milk and dairy products? } \\
\hline & & Mean & $\mathrm{KW}(\mathrm{H})$ & KW(p) \\
\hline \multirow{2}{*}{ Gender } & male & 3.74 & \multirow[b]{2}{*}{0.400} & \multirow[b]{2}{*}{0.527} \\
\hline & female & 3.78 & & \\
\hline \multirow{4}{*}{ Class } & 1. class & 3.80 & \multirow{4}{*}{1.892} & \multirow{4}{*}{0.595} \\
\hline & 2. class & 3.74 & & \\
\hline & 3. class & 3.85 & & \\
\hline & 4. class & 3.67 & & \\
\hline \multirow{3}{*}{ Environment } & urban & 3.79 & \multirow{3}{*}{1.576} & \multirow{3}{*}{0.455} \\
\hline & suburban & 3.68 & & \\
\hline & rural & 3.85 & & \\
\hline
\end{tabular}

By analyzing the responses of male students (3.61) and female students (3.41), there are no statistically significant differences in the consumption of bread, dough and pastry. In the answers of students of the first class (3.61), second class (3.49), third class (3.66) and fourth class (3.56) there are no statistically significant differences. In the answers of students from the urban environment (3.58), from the suburban environment (3.62), and the rural environment (3.51) there are no statistically significant differences. (Table 6).

Table 6. Odgovori učenika o konzumiranju hleba, testa i peciva prema polu, razredu i sredini iz koje dolaze učenici

\begin{tabular}{|c|c|c|c|c|}
\hline \multicolumn{5}{|c|}{ How much do you eat bread, dough and pastries? } \\
\hline \multirow{3}{*}{ Gender } & & Mean & KW(H) & KW(p) \\
\hline \multirow{4}{*}{ Class } & male & 3.61 & \multirow{2}{*}{0.565} & \multirow{2}{*}{0.452} \\
\cline { 2 - 3 } & female & 3.41 & & \\
\cline { 2 - 3 } & 1. class & 3.61 & \multirow{2}{*}{1.114} & \multirow{2}{*}{0.767} \\
\cline { 2 - 3 } & 2. class & 3.49 & \\
\cline { 2 - 3 } & 3. class & 3.66 & & \\
\cline { 2 - 3 } & 4. class & 3.56 & & \\
\hline
\end{tabular}




\begin{tabular}{|c|c|c|c|c|}
\hline \multirow{3}{*}{ Environment } & urban & 3.58 & \multirow{2}{*}{} \\
\cline { 2 - 3 } & suburban & 3.62 & \multirow{2}{*}{0.672} & 0.715 \\
\cline { 2 - 3 } & rural & 3.51 & & \\
\hline
\end{tabular}

Analizom odgovora učenika muškog pola (3.47) i ženskog pola (3.59) postoje statistički značajne razlike u konzumiranju voća i povrća. U odgovorima učenika prvog razreda (3.01), drugog razreda (2.94), trećeg razreda (3.16) i četvrtog razreda (3.04) nema statistički značajnih razlika. U odgovorima učenika iz gradske sredine (3.08), iz prigradske sredine (2.99), i seoske sredine (3.04) postoje statistički značajne razlike (Table 7).

Table 7. Students' responses to the consumption of fruits and vegetables by gender, class, and environment from which they come

\begin{tabular}{|c|c|c|c|c|}
\hline \multicolumn{5}{|c|}{ How much do you consume fruits and vegetables? } \\
\hline & & Mean & $\mathrm{KW}(\mathrm{H})$ & $\mathrm{KW}(\mathrm{p})$ \\
\hline \multirow{2}{*}{ Gender } & male & 3.47 & \multirow{2}{*}{0.655} & \multirow{2}{*}{0.418} \\
\hline & female & 3.59 & & \\
\hline \multirow{4}{*}{ Class } & 1. class & 3.59 & \multirow{4}{*}{5.389} & \multirow{4}{*}{0.146} \\
\hline & 2. class & 3.73 & & \\
\hline & 3. class & 3.45 & & \\
\hline & 4. class & 3.33 & & \\
\hline \multirow{3}{*}{ Environment } & urban & 3.58 & \multirow{3}{*}{6.214} & \multirow{3}{*}{0.045} \\
\hline & suburban & 3.62 & & \\
\hline & rural & 3.51 & & \\
\hline
\end{tabular}

By analyzing the responses of male students (4.07) and female students (3.94), there are no statistically significant differences in the consumption of cakes and sweets. In the answers of the students of the first class (4.14), the second class (3.96), the third class (4.03) and the fourth class (3.90) there are no statistically significant differences. There are no statistically significant differences in the answers of students from the urban environment (3.96), from the suburban environment (3.96), and the rural environment (3.92) (Table 8). 
Table 8. Answers of students about consuming cakes and sweets by gender, class, and environment from which they come

\begin{tabular}{|c|c|c|c|c|}
\hline \multicolumn{5}{|c|}{ How much do you consume cakes and sweets? } \\
\hline & & Mean & $\mathrm{KW}(\mathrm{H})$ & $\mathrm{KW}(\mathrm{p})$ \\
\hline \multirow{2}{*}{ Gender } & male & 4.07 & \multirow{2}{*}{1.434} & \multirow{2}{*}{0.231} \\
\hline & female & 3.94 & & \\
\hline \multirow{4}{*}{ Class } & 1. class & 4.14 & \multirow{4}{*}{2.154} & \multirow{4}{*}{0.541} \\
\hline & 2. class & 3.96 & & \\
\hline & 3. class & 4.03 & & \\
\hline & 4. class & 3.90 & & \\
\hline \multirow{3}{*}{ Environment } & urban & 3.96 & \multirow{3}{*}{1.125} & \multirow{3}{*}{0.570} \\
\hline & suburban & 3.96 & & \\
\hline & rural & 3.92 & & \\
\hline
\end{tabular}

By analyzing the responses of male students (3.34) and female students (3.29) there are statistically significant differences in the consumption of water and fruit juices. In the answers of students of the first class (3.10), second class (3.41), third class (3.29) and fourth class (3.14) there are no statistically significant differences. In the answers of students from the urban environment (3.25), from the suburban environment (3.32), and the rural environment (3.40) there are no statistically significant differences (Table 9).

Table 9. Answers of students about consuming water and fruit juices by gender, class and environment from which they come

\begin{tabular}{|c|c|c|c|c|}
\hline \multicolumn{5}{|c|}{ How much do you consume water and fruit juices? } \\
\hline \multirow{3}{*}{ Gender } & & Mean & KW(H) & KW(p) \\
\hline \multirow{4}{*}{ Class } & male & 3.34 & \multirow{2}{*}{0.270} & 0.603 \\
\cline { 2 - 3 } & female & 3.29 & & \\
\hline \multirow{3}{*}{ Environment } & 1. class & 3.10 & & \multirow{2}{*}{0.352} \\
\cline { 2 - 3 } & 2. class & 3.41 & \multirow{2}{*}{3.272} & \\
\cline { 2 - 3 } & 3. class & 3.29 & & \\
\cline { 2 - 3 } & 4. class & 3.14 & & \multirow{2}{*}{0.710} \\
\cline { 2 - 3 } & urban & 3.25 & & \\
\hline
\end{tabular}


By analyzing the responses of male students (3.91) and female students (3.78) there are statistically significant differences in the consumption of energy and carbonated drinks. In the answers of the students of the first class (4.06), the second class (3.82), the third class (3.88) and the fourth class (3.62) there are no statistically significant differences. In the answers of students from the urban environment (3.83), from the suburban environment (3.78) and rural areas (3.92) there are no statistically significant differences (Table 10).

Table 10. Answers of students about consuming energy and carbonated drinks by gender, class and environment from which they come

\begin{tabular}{|c|c|c|c|c|}
\hline \multicolumn{5}{|c|}{ How much do you consume energy and carbonated drinks? } \\
\hline & & Mean & KW(H) & $\mathrm{KW}(\mathrm{p})$ \\
\hline \multirow{2}{*}{ Gender } & male & 3.91 & \multirow[b]{2}{*}{0.510} & \multirow[b]{2}{*}{0.475} \\
\hline & female & 3.78 & & \\
\hline \multirow{4}{*}{ Class } & 1. class & 4.06 & \multirow{4}{*}{4.467} & \multirow{4}{*}{0.215} \\
\hline & 2. class & 3.82 & & \\
\hline & 3. class & 3.88 & & \\
\hline & 4. class & 3.62 & & \\
\hline \multirow{3}{*}{ Environment } & urban & 3.83 & \multirow{3}{*}{0.047} & \multirow{3}{*}{0.977} \\
\hline & suburban & 3.78 & & \\
\hline & rural & 3.92 & & \\
\hline
\end{tabular}

In Figure 1. graphs show the percentage values of all pupils on eating habits of each investigated food group.

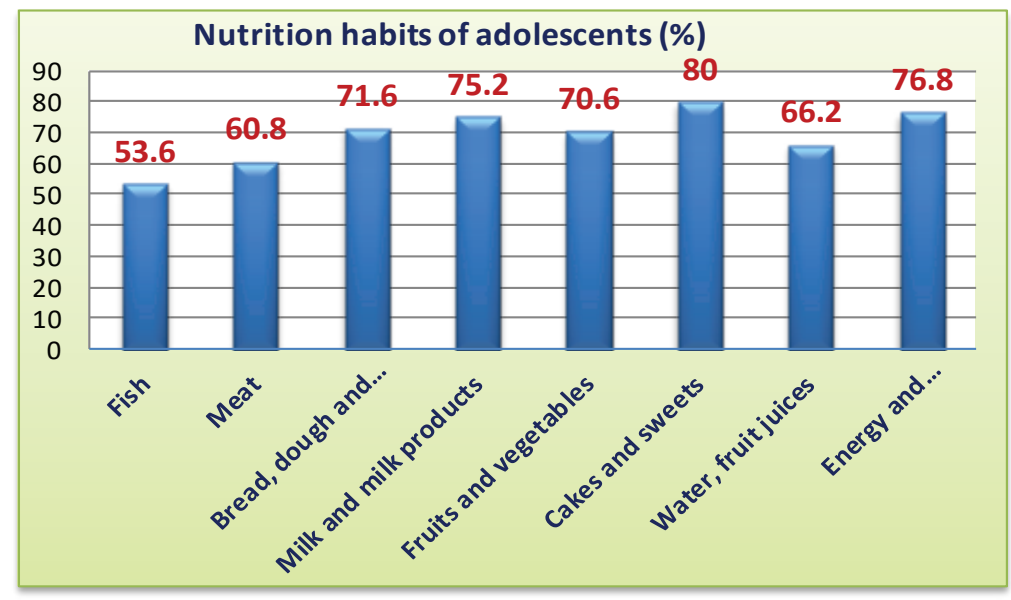

Figure 1. Eating habits of adolescents by groups of foods tested. 
The third group of questions was related to diet. By analyzing the responses of male students (3.73) and female students (3.61), there are no statistically significant differences in nutrition in the home or outside. In the answers of the students of the first class (3.85), the second class (3.69), the third class (3.38) and the fourth class (3.71) there are no statistically significant differences. In the answers of students from the urban environment (3.72), from the suburban environment (3.41), and the rural environment (3.94) there are statistically significant differences (Tabela 11).

Table 11. Answers of students about diet by gender, class and environment from which they come

\begin{tabular}{|c|c|c|c|c|}
\hline \multicolumn{5}{|c|}{ Do you eat more in the house than outdoors? } \\
\hline \multirow{3}{*}{ Gender } & & Mean & KW(H) & KW(p) \\
\hline \multirow{4}{*}{ Class } & male & 3.73 & \multirow{2}{*}{0.536} & \multirow{2}{*}{0.215} \\
\cline { 2 - 3 } & female & 3.61 & & \\
& 1. class & 3.85 & & \multirow{2}{*}{0.087} \\
\cline { 2 - 3 } & 2. class & 3.69 & \multirow{2}{*}{6.577} & \\
\cline { 2 - 3 } & 3. class & 3.38 & & \\
\cline { 2 - 3 } Environment & 4. class & 3.71 & \multirow{2}{*}{6.266} & \multirow{2}{*}{$\mathbf{0 . 0 4 4}$} \\
\cline { 2 - 3 } & urban & 3.72 & \\
\cline { 2 - 3 } & suburban & 3.41 & & \\
\hline
\end{tabular}

By analyzing students' responses to the existence of health problems or hereditary diseases, there are no statistically significant differences among male students (1.59) and female students (1.68). In the answers of the students of the first class (1.68), the second class (1.73), the third class (1.56) and the fourth class (1.64) there are no statistically significant differences. In the answers of students from the urban environment (1.73), from the suburban environment (1.64) and the rural environment (1.52) there are no statistically significant differences (Table 12).

Tabela 12. Student's responses to health problems or hereditary diseases by gender, class and environment from which they come

\begin{tabular}{|c|c|c|c|c|}
\hline \multicolumn{5}{|c|}{ Do you have health problems or inherited diseases? } \\
\hline \multirow{2}{*}{ Gender } & & Mean & KW(H) & KW(p) \\
\cline { 2 - 5 } & male & 1.59 & \multirow{2}{*}{0.739} & 0.390 \\
\hline
\end{tabular}




\begin{tabular}{|c|c|c|c|c|}
\hline \multirow{3}{*}{ Class } & 1. class & 1.73 & \multirow{2}{*}{} & \multirow{2}{*}{0} \\
\cline { 2 - 3 } & 2. class & 1.56 & \multirow{2}{*}{0.453} & \\
\cline { 2 - 3 } & 3. class & 1.65 & \\
\cline { 2 - 3 } & 4. class & 1.64 & & \\
\hline \multirow{3}{*}{ Environment } & urban & 1.73 & \multirow{2}{*}{0.090} & \multirow{2}{*}{0.956} \\
\cline { 2 - 3 } & suburban & 1.64 & \\
\cline { 2 - 3 } & rural & 1.52 & & \\
\hline
\end{tabular}

By analyzing students' responses regarding diet, among male students (1.62) and female students (2.04), there are statistically significant differences. In the answers of students of the first class (2.04), second class (1.80), third class (1.72) and fourth class (1.87) there are no statistically significant differences. There are no statistically significant differences in the answers of students from the urban environment (1.87), from the suburban environment (1.87), and the rural environment (1.77 (Table 13).

Table 13. Answers of students about diet by gender, class and environment from which they come

\begin{tabular}{|c|c|c|c|c|}
\hline \multicolumn{5}{|c|}{ Da li ste nekada držali dijetu? } \\
\hline \multirow{3}{*}{ Gender } & & Mean & KW(H) & KW(p) \\
\hline \multirow{4}{*}{ Class } & male & 1.62 & \multirow{2}{*}{10.436} & \multirow{2}{*}{$\mathbf{0 . 0 0 1}$} \\
\cline { 2 - 3 } & female & 2.04 & & \\
\cline { 2 - 3 } & 1. class & 2.04 & \multirow{2}{*}{3.713} & \multirow{2}{*}{0.294} \\
\cline { 2 - 3 } & 2. class & 1.80 & \\
\cline { 2 - 3 } & 3. class & 1.84 & \\
\cline { 2 - 3 } Environment & 4. class & 1.72 & \multirow{2}{*}{0.771} & \multirow{2}{*}{0.680} \\
\cline { 2 - 3 } & urban & 1.87 & \\
\cline { 2 - 3 } & suburban & 1.87 & & \\
\cline { 2 - 3 } & rural & 1.77 & & \\
\hline
\end{tabular}

By analyzing students' responses to the effect of diets on health, there are no statistically significant differences between male students (2.54) and female students (2.55). In the answers of students of the first class (2.56), second class (2.61), third class (2.42) and fourth class (2.58) there are no statistically significant differences. In the answers of students from the urban environment (2.53), there are no statistically significant differences from the suburban environment (2.48) and the rural environment (2.67) (Table 14). 
Table 14. Answers of students about diet by gender, class and environment from which they come

\begin{tabular}{|c|c|c|c|c|}
\hline \multicolumn{5}{|c|}{ Do you think the diet affects health? } \\
\hline & & Mean & $\mathrm{KW}(\mathrm{H})$ & $\mathrm{KW}(\mathrm{p})$ \\
\hline \multirow{2}{*}{ Gender } & male & 2.54 & \multirow{2}{*}{0.004} & \multirow{2}{*}{0.949} \\
\hline & female & 2.55 & & \\
\hline \multirow{4}{*}{ Class } & 1. class & 2.56 & \multirow{4}{*}{4.467} & \multirow{4}{*}{0.215} \\
\hline & 2. class & 2.61 & & \\
\hline & 3. class & 2.42 & & \\
\hline & 4. class & 2.58 & & \\
\hline \multirow{3}{*}{ Environment } & urban & 2.53 & \multirow{3}{*}{4.916} & \multirow{3}{*}{0.086} \\
\hline & suburban & 2.48 & & \\
\hline & rural & 2.67 & & \\
\hline
\end{tabular}

By analyzing the student's answer to the question of whether proper diet can alleviate or prevent some diseases, such as diabetes, cholesterol, and others, there are statistically significant differences between male students (4.29) and female students (3.95), namely male students. Conscious that healthy foods can avoid certain diseases. There are statistically significant differences in the answers of the students of the first class (4.46), the second class (4.10), the third class (3.77) and the fourth class (4.12). In the answers of students from the urban environment (4.10), from the suburban environment (4.05), and the rural environment (4.20) there are no statistically significant differences (Table 15).

Table 15. Answers of students about diet by gender, class and environment from which they come

Do you think that proper nutrition can alleviate or prevent some diseases such as: diabetes, cholesterol, and others?

\begin{tabular}{|c|c|c|c|c|}
\hline & & Mean & $\mathrm{KW}(\mathrm{H})$ & $K W(p)$ \\
\hline \multirow{2}{*}{ Gender } & male & 4.29 & \multirow{2}{*}{6.985} & \multirow{2}{*}{0.008} \\
\hline & female & 3.95 & & \\
\hline \multirow{4}{*}{ Class } & 1. class & 4.46 & \multirow{4}{*}{11.686} & \multirow{4}{*}{0.009} \\
\hline & 2. class & 4.10 & & \\
\hline & 3. class & 3.77 & & \\
\hline & 4. class & 4.12 & & \\
\hline \multirow{3}{*}{ Environment } & urban & 4.10 & \multirow{3}{*}{0.396} & \multirow{3}{*}{0.821} \\
\hline & suburban & 4.05 & & \\
\hline & rural & 4.20 & & \\
\hline
\end{tabular}


By analyzing students' responses to regular breakfast, there are statistically significant differences between male (4.10) and female students (3.80), meaning that male students are more aware that healthy food can avoid certain diseases. There are statistically significant differences in the answers of the students of the first class (4.46), the second class (4.10), the third class (3.77) and the fourth class (4.12). In the answers of students from the urban environment (4.10), from the suburban environment (4.05), and the rural environment (4.20) there are no statistically significant differences (Table 16).

Table 16. Answers of students about diet by gender, class and environment from which they come

\begin{tabular}{|c|c|c|c|c|}
\hline \multicolumn{5}{|c|}{ Do you have regular breakfast? } \\
\hline & & Mean & $\mathrm{KW}(\mathrm{H})$ & $\mathrm{KW}(\mathrm{p})$ \\
\hline \multirow{2}{*}{ Gender } & male & 3.99 & \multirow{2}{*}{6.771} & \multirow{2}{*}{0.009} \\
\hline & female & 3.63 & & \\
\hline \multirow{4}{*}{ Class } & 1. class & 3.74 & \multirow{4}{*}{0.163} & \multirow{4}{*}{0.983} \\
\hline & 2. class & 3.82 & & \\
\hline & 3. class & 3.80 & & \\
\hline & 4. class & 3.81 & & \\
\hline \multirow{3}{*}{ Environment } & urban & 3.93 & \multirow{3}{*}{3.064} & \multirow{3}{*}{0.216} \\
\hline & suburban & 3.82 & & \\
\hline & rural & 3.60 & & \\
\hline
\end{tabular}

The second part of the study was to examine the risk of diabetes type 2, using a standardized questionnaire, which students voluntarily filled out. A total of 111 students, 48 (43.2\%) male, and 63 (56.7\%) females completed the online questionnaire and there were no statistically significant differences in the ratio of male and female respondents in the sample to the risk of diabetes type 2 . The risk results are in degree: low have $79.2 \%$ of students, $14.5 \%$ are in an elevated degree, $2.1 \%$ of students have a moderate risk and $4.2 \%$ are at high risk for type 2 diabetes, while there are no students at very high-risk degree. In low-risk female students are $76.2 \%$ of students, $15.9 \%$ are easily raised, $3.2 \%$ of students have a moderate risk, and $4.7 \%$ have a high risk of type 2 diabetes, while there are no students at very high risk (Table 17). 
Table 17. The results of examining the student's risk of developing type 2 diabetes by gender

\begin{tabular}{|c|c|c|c|c|}
\hline Gender & Percentage & Risk & $\mathrm{KW}(\mathrm{H})$ & $K W(p)$ \\
\hline \multirow{5}{*}{$\begin{array}{c}\text { male } \\
(48) \\
(43.2 \%)\end{array}$} & 79.2 & Low & \multirow{10}{*}{2.027} & \multirow{10}{*}{0.155} \\
\hline & 14.5 & Easy elevated & & \\
\hline & 2.1 & Moderate & & \\
\hline & 4.2 & High & & \\
\hline & 0.0 & Very high & & \\
\hline \multirow{5}{*}{$\begin{array}{c}\text { female } \\
(63) \\
(56.7 \%)\end{array}$} & 76.2 & Low & & \\
\hline & 15.9 & Easy elevated & & \\
\hline & 3.2 & Moderate & & \\
\hline & 4.7 & High & & \\
\hline & 0.0 & Very high & & \\
\hline
\end{tabular}

Measured values of BMI greater than 30 are found in $6.2 \%$ of male students and $7.9 \%$ female students, values between 25 and 30 are $14.6 \%$ of male students and $22.2 \%$ female, and with less than 25 , the vast majority is $79.2 \%$ male students and $69.9 \%$ female students. Measured values of the volume of waist greater than 102 are found in $6.2 \%$ of male students, values between 94 and 102 are found in $14.6 \%$ of students, and with less than 94 , the vast majority are $79.2 \%$ of students. Measured values of the volume of waist greater than 88 are found in $7.9 \%$ female students, values between 80 and 88 are found in $7.9 \%$ female students, and with a smaller than 80 , the vast majority are $79.4 \%$ of students. There are no statistically significant differences in BMI values and measured values of waist circumference for male and female students (Table 18).

Table 18. Percentage of students according to BMI and waist size by gender

\begin{tabular}{|c|c|c|c|c|c|c|}
\hline \multirow{4}{*}{ male } & $\begin{array}{c}\text { BMI } \\
(\%)\end{array}$ & \multicolumn{2}{|c|}{ Values } & $\begin{array}{c}\text { Waist size } \\
(\%)\end{array}$ & \multicolumn{2}{c|}{ Values } \\
\hline \multirow{4}{*}{} & 6.2 & $>30$ & 3 & 6.2 & $>102$ & 4 \\
\cline { 2 - 7 } & 14.6 & $25-30$ & 1 & 14.6 & $94-102$ & 3 \\
\cline { 2 - 7 } & 79.2 & $<25$ & 0 & 79.2 & $<94$ & 0 \\
\hline \multirow{4}{*}{ female } & 7.9 & $>30$ & 3 & 7.9 & $>88$ & 4 \\
\cline { 2 - 7 } & 22.2 & $25-30$ & 1 & 12.7 & $80-88$ & 3 \\
\hline \multirow{4}{*}{} & 69.9 & $<25$ & 0 & 79.4 & $<80$ & 0 \\
\hline & $\mathrm{KW}(\mathrm{H})$ & $\mathrm{KW}(\mathrm{p})$ & & $\mathrm{KW}(\mathrm{H})$ & $\mathrm{KW}(\mathrm{p})$ & \\
\hline & 0.318 & 0.573 & & 0.000 & 0.983 & \\
\hline
\end{tabular}


The percentage of students who used antihypertensive drugs was $4.2 \%$ for males, $3.2 \%$ for females, and those who did not use antihypertensive drugs in male was $95.8 \%$ and for females $96.8 \%$. The percentage of students in whom elevated sugar is measured is in the male ratio of $4.2 \%$, in the female half $4.8 \%$, and those who have not measured the elevated sugar in the male is $95.8 \%$, the female is $95.2 \%$. There are no statistically significant differences in the percentage of students using antihypertensive drugs, nor in the percentage of students in whom elevated sugar is measured, depending on males and females (Table 19).

Table 19. Percentage of students who use antihypertensive drugs and students who measured the value of sugar by sex

\begin{tabular}{|c|c|c|c|c|c|c|}
\hline \multirow{2}{*}{ male } & Antihypertensive (\%) & \multicolumn{2}{|c|}{ Values } & \multicolumn{2}{c|}{$\begin{array}{c}\text { Sugar } \\
\text { (\%) }\end{array}$} & \multicolumn{2}{c|}{ Values } \\
\cline { 2 - 8 } & 4.2 & $\mathrm{Da}$ & 2 & 4.2 & $\mathrm{Da}$ & 5 \\
\hline \multirow{3}{*}{ female } & 95.8 & $\mathrm{Ne}$ & 0 & 95.8 & $\mathrm{Ne}$ & 0 \\
\cline { 2 - 8 } & 3.2 & $\mathrm{Da}$ & 2 & 4.8 & $\mathrm{Da}$ & 5 \\
\hline \multirow{3}{*}{} & 96.8 & $\mathrm{Ne}$ & 0 & 95.2 & $\mathrm{Ne}$ & 0 \\
\hline & $\mathrm{KW}(\mathrm{H})$ & $\mathrm{KW}(\mathrm{p})$ & & $\mathrm{KW}(\mathrm{H})$ & $\mathrm{KW}(\mathrm{p})$ & \\
\hline & 0.022 & 0.881 & & 0.076 & 0.782 & \\
\hline
\end{tabular}

The greatest impact of hereditary risk factors for diabetes mellitus type 2 in male students from the immediate family is $16.7 \%$, and female students $7.9 \%$. The impact of hereditary factors from members of the wider family in male students is $18.8 \%$, and female students $12.7 \%$. Without the influence of hereditary factors, $64.5 \%$ of male students and $79.4 \%$ of female students is probability (Table 20 ).

Table 20. Percentage of students with inherited risks of type 2 diabetes by gender

\begin{tabular}{|c|c|c|c|c|c|}
\hline \multirow{4}{*}{} & $\begin{array}{c}\text { Hereditary factors } \\
\text { (\%) }\end{array}$ & \multicolumn{2}{|c|}{ Points } & \multirow{2}{*}{ KW(H) } & \multirow{2}{*}{ KW(p) } \\
\hline \multirow{3}{*}{ male } & 16.7 & Yes (close family) & 5 & & \\
\cline { 2 - 4 } & 18.8 & Yes (whole family) & 3 & & \\
\hline \multirow{3}{*}{ female } & 64.5 & No & 0 & & \multirow{2}{*}{3.173} \\
\cline { 2 - 4 } & 7.9 & Yes (close family) & 5 & \multirow{2}{*}{0.075} \\
\cline { 2 - 4 } & 12.7 & Yes (whole family) & 3 & & \\
\hline
\end{tabular}




\section{Conclusion}

Analyzing the eating habits of adolescents, it can be concluded that they do not differ too much, depending on half of the students. (15) Fewer gender differences exist in the habits of certain foods. From the previous analysis, it can be concluded that male students consume more meat by about $7.5 \%$ compared to female students. Also, female students by $8.3 \%$ more hold the child than male students. Male pupils by $7.2 \%$ more often have breakfast than female students. Observed in the center from which they come, fish are mostly consumed by students from the suburban environment by $8 \%$ more than in urban and rural areas. Fruits and vegetables are about $2.5 \%$ more consumed by students from the suburban environment than from urban and rural areas. The largest percentage of $10 \%$ of rural students consumes food at home, compared to students in urban and suburban environments. While differences in attitudes about the impact of proper nutrition on the emergence of chronic non-communicable diseases differ in both the sex and the meanings from which they come. (16), (17) Our assumed assumption is not sustainable, and we accept the alternative hypothesis of the first hypothesis $\mathrm{H} 1$.

General habits in the adolescent diet are not the best because they consume: cakes and sweets $80 \%$, energy and carbonated drinks $76.8 \%$, bread and pastry bread $71.6 \%$ (Figure 1). The results of the standardized questionnaire show that $4.2 \%$ of male students and $4.7 \%$ of female students at high risk for type 2 diabetes. (18) At moderate risk, $2.1 \%$ are male and $3.2 \%$ female students. In an increased risk, $14.5 \%$ of male students and $15.9 \%$ of female students (Table 15).

Taking into account eating habits and current results of risk assessment for diabetes in students aged 14 to 18 , preventive action is necessary, (19) in order to reduce the risk and mitigate as much as possible (14). We can confirm the implied assumption that the risk of developing type 2 diabetes in both males and females is lower than $15 \%$ and that the $\mathrm{H} 2$ hypothesis can be accepted.

It is necessary to suggest to students who are at a high and moderate risk of doing the OGTT test in order to eliminate or confirm the above-mentioned concerns about diabetes. (20), (21) All students should be introduced to the consequences of improper diet and diseases that can arise as their consequence.

\section{References}

1. M. Dokić, M. Jevtić, D. Balać, Prevention of type 2 diabetes mellitus in children and adolescents, Medical Bulletin, 1452-09231141050D, 2011.

2. Ž. Lalić, K. Rašković, Risk assessment for diabetes mellitus type 2 in health care workers, General medicine, UDC 616.379-008.64-05, 716(3-4);138-142, 2010. 
3. Incidence and Mortality from Diabetes in Serbia, Institute of Public Health „Milan Jovanović Batut, 2017.

4. MedicineWorld.Org - Endocrinology-Type 2 diabetes, Your gateway to information on type 2 diabetes; http://www.medicineworld.org/medicine/endocrinology/type2diabetes. html

5. M. Dumić, A. Š. Uroić, Diabetes mellitus in adolescents, Pediatric Clinic of the Faculty of Medicine, University of Zagreb, KBC Zagreb, MEDICUS 2010; Vol. 19, No. 1, $27-34$.

6. R. Vuković, D. Zdravković. Frequency of glucose regulation in obese children adolescents in Serbia. Medical Bulletin Special Hospital for thyroid gland diseases metabolism. Zlatibor 2012; 17: 92-105.

7. G. Švonja-Parezanović, B. Perić-Prkosovački, Nutrition and habits in the diet of young people. PONS Med čas, 2014; 11: 48-52.

8. G. Bukara-Radujković, D. Zdravković, Determinants of obesity in children and adolescents. Srp Arh Celok Lek 2008; 136: 22-7.

9. About BMI for Children and Teens. Atalanta: Centers for Disease Control and Prevention, 2015. http://www.cdc.gov/healthyweight/assessing/bmi/childrens_bmi/about_childrens_bmi.html

10. SR. Daniels, DK. Arnett, RH. Eckel, et al. Overweight in children and adolescents: pathophysiology, consequences, prevention, and treatment. Circulation 2005; 111 : 1999-2002.

11. The Diabetes Control and Complications Trial Research Group. The absence of aglycaemic treshold for the development of long-term complications: the perspective of DCCT. Diabetes 1996; 45: 1289-98.

12. SPSS Statistical, available: https://www.ibm.com/products/spss-statistics.

13. Working in SPSS, available: http://stat.uns.ac.rs/LLLprogramme/NP/TeachingMaterial/ Uputstvo.pdf

14. I. Jevtović, Medicinska statistika. Kragujevac: Medicinski fakultet, 2008.

15. American Diabetes Association: Type 2 diabetes in children and adolescents. American Diabetes Association. Pediatrics 2000;105: 671-80.6.

16. F. Chiarellif, C. Giannini, A. Mohn A., Growth, growth factors and diabetes. Eur J Endocrinol. 2004;151 (Suppl 3): U109-17.

17. J. Lebl, E. Schober, T. Zidek et al., Growth data in large series of 587 children and adolescents with type 1 diabetes mellitus. Endocr Regul 2003; 37: 153-61.

18. Cl. Cacerinini, RM. Williams, DB, Dunger, Metabolic impact of puberty on the course of type 1 diabetes. Diabetes Metab 2001; 27: S19-25.

19. Y. Xin, A. Davies, L. McCombie, A. Briggs, CM Messow, E. Grieve, et al., Type 2 diabetes remission: economic evaluation of the DiRECT/Counterweight-Plus weight management programme within a primary care randomized controlled trial, Med. 2019. doi: $10.1111 / \mathrm{dme} .13981$

20. Z. Liu, C. Fu, W. Wang, B.Xu, Prevalence of chronic complications of type 2 diabetes mellitus in outpatients - a crosssectional hospital based survey in urban China. Health Qual Life Outcomes 2010; 8: 62. 
21. WC. Chumlea, CM. Schubert, AF. Roche et al, Age at menarche and racial comparisons in US girls. Pediatrics. 2003; 111: 110-3.

22. B. Anderson, J. Ho, J. Brackett, D. Finkelstein, L. Laffel, Parental involvement in diabetes management tasks: relationships to blood glucose monitoring adherence and metabolic control in young adolescents with insulin-dependent diabetes mellitus. J Pediatr 1997; 130: $257-65$. 